\title{
The 6-float wave energy converter M4: Ocean basin tests giving capture width, response and energy yield for several sites
}

DOI:

10.1016/j.rser.2019.01.033

\section{Document Version}

Accepted author manuscript

Link to publication record in Manchester Research Explorer

Citation for published version (APA):

Carpintero Moreno, E., \& Stansby, P. (2019). The 6-float wave energy converter M4: Ocean basin tests giving capture width, response and energy yield for several sites. Renewable and Sustainable Energy Reviews, 104, 307-318. https://doi.org/10.1016/j.rser.2019.01.033

\section{Published in:}

Renewable and Sustainable Energy Reviews

\section{Citing this paper}

Please note that where the full-text provided on Manchester Research Explorer is the Author Accepted Manuscript or Proof version this may differ from the final Published version. If citing, it is advised that you check and use the publisher's definitive version.

\section{General rights}

Copyright and moral rights for the publications made accessible in the Research Explorer are retained by the authors and/or other copyright owners and it is a condition of accessing publications that users recognise and abide by the legal requirements associated with these rights.

\section{Takedown policy}

If you believe that this document breaches copyright please refer to the University of Manchester's Takedown Procedures [http://man.ac.uk/04Y6Bo] or contact uml.scholarlycommunications@manchester.ac.uk providing relevant details, so we can investigate your claim.

\section{OPEN ACCESS}


The 6-float wave energy converter M4: ocean basin tests giving capture width, response and energy yield for several sites

\section{Efrain Carpintero Moreno and Peter Stansby}

School of Mechanical, Aerospace and Civil Engineering, University of Manchester

Abstract: The M4 wave energy converter originally consisted of three in-line floats increasing in diameter (and draft) from bow to stern so that the device heads naturally into the wave direction with power take off (PTO) from a hinge above the mid float. Linear diffraction modelling was found to make quite accurate predictions of power and response. Time domain modelling was extended to a larger number of floats, up to eight with four PTOs, by Stansby et al (Applied Ocean Research, 2017, 68, 53-64). This showed that capacities similar to wind turbines were possible for some sites. Experimental comparison is presented here for a six-float system with two PTOs. For irregular unidirectional waves with JONSWAP spectra measured power was a little larger than that modelled with maximum capture widths greater than one wave length for energy period. Results for angular motion at the PTOs and mooring forces are presented. Wave conditions with different spectral peakedness and multi-directional spreading are applied and energy yield with electricity cost estimates made for 11 offshore sites. Without PTO to give worst case response, results are presented for angular motion and mooring force variation with significant wave height up to extreme values for different peak periods. Angular motion is predominantly linear but mooring force is more complex with largest values in extreme waves occurring in the range of periods for operational conditions.

Keywords: wave energy conversion; capture width; multi-float; multi-mode; ocean basin testing; annual energy yield.

1. Introduction

Wave energy is a massive renewable energy resource which has yet to be exploited for conversion into electricity although many devices have been considered, see reviews [1,2] for example. The wave resource is greatest offshore in deeper water and various forms of point absorber have received attention. However energy capture is limited for predominantly heave motion and hinged raft-type devices with two bodies connected by a hinge for power take off (PTO) have the potential to increase this through several modes of excitation. The Cockerel raft in the 1980s was an early form of this concept, sometimes called an attenuator. The well known Pelamis device extended this concept with several (three or four) cylindrical tube bodies connected by hinges each with a PTO [3]. A system of two box-type floats connected rigidly by a beam with a hinge for PTO connected to a third float by a beam was developed by Sea Power [4]. The M4 device extends this concept further by using cylindrical (vertical axis) floats to avoid losses due to external sloshing and the floats have hemi-spherical or rounded bases to give minimal drag losses. Different sizes of float give a range of natural periods to enable power capture across a range of wave periods for an offshore site. A single bow float is attached to a mooring buoy and the floats increase in diameter and volume from bow to stern; drift forces increase with distance from the buoy causing the device to head naturally in the wave direction. The initial device had three floats with distance between floats of about half a typical wavelength so that adjacent float motions are predominantly in anti-phase [5]. The bow and mid floats are rigidly connected by a beam, effectively forming a single body, and a beam from the 
stern float is connected to the hinge point above the mid float for power take off (PTO). The appropriateness of Froude scaling for such a system has been demonstrated through laboratory experiments at two scales differing by a factor of five [6]. A linear frequency domain diffraction model has been shown to give good prediction of relative pitch rotation about the hinge and variable prediction of power absorption in regular [7] and irregular waves [8,9]. Drag effects were assumed to be negligible and this has been supported by computational fluid dynamics for idealised motion of single floats [10]. The prediction of power was remarkably accurate for irregular, multidirectional waves, less accurate for uni-directional irregular waves and least accurate for regular waves. Although wave basin reflection was small, less than $10 \%$ in $[5,7,8]$, this does suggest that the effect (in regular waves) could be significant in a confined (albeit large) wave basin since any effect will be reduced for irregular and multi-directional waves when frequency averaged. Independent linear diffraction modelling, in the time domain, has shown that increasing the length of beam between bow and mid floats increased power capture [11] and this was verified experimentally, as presented in [12]. The number of floats in the model was generalised in [12], keeping a single bow float but increasing the number of mid floats (the bow and mid floats still acting as an effectively rigid body) and the number of stern floats, each with a damper on a hinge above the mid floats. The aim was to increase capacity and reduce electricity cost; this was demonstrated and estimates for several sites indicated that capacity and cost could be similar to wind turbines. Clearly experimental validation is desirable. The six float configuration was found to be marginally the most cost effective along with the four float version [12]. The six float, more hydrodynamically complex configuration with larger capacity has been chosen for investigation here, with one bow float, three mid floats and two stern floats. Such complex configurations have not been investigated previously to our knowledge. Response, power output and mooring force have been measured in operational conditions and response and mooring forces in extreme conditions without power take off to give worst case response.

The paper is structured as follows. The tests at about 1:50 scale undertaken in the Lir Ocean Basin at the Beaufort Centre, University College Cork are described in the following section, results are then presented, some cost estimates are made for several sites and finally there is some discussion and conclusions are drawn.

\section{Ocean basin tests}

The tests were undertaken in the Lir Ocean Basin, University College Cork (UCC), Ireland. This has a curved line of 80 Edinburgh Design wave paddles with sloping beaches on two sides as shown in Fig. 1 provided by UCC.

The six float configuration is shown in Fig.2a with dimensions in Fig.2b (plan) and 2c (elevation). To minimise the effect of reflections it is desirable that reflected waves only reach the working area for the device after reflection for a second time from a beach. An appropriate angle for wave propagation was estimated based simply on total internal reflection (ignoring refraction). Complete avoidance of single reflection within a working area was not thought possible but it was minimised for wave propagation at $63^{\circ}$ to the original wave direction, i.e. at $27^{\circ}$ to the bottom row of paddles. To test this a group of regular waves (about 10 ) was generated and wave probes showed that after their initial passage reflected amplitudes were less than $10 \%$ of the original. This wave direction was used for all tests. 


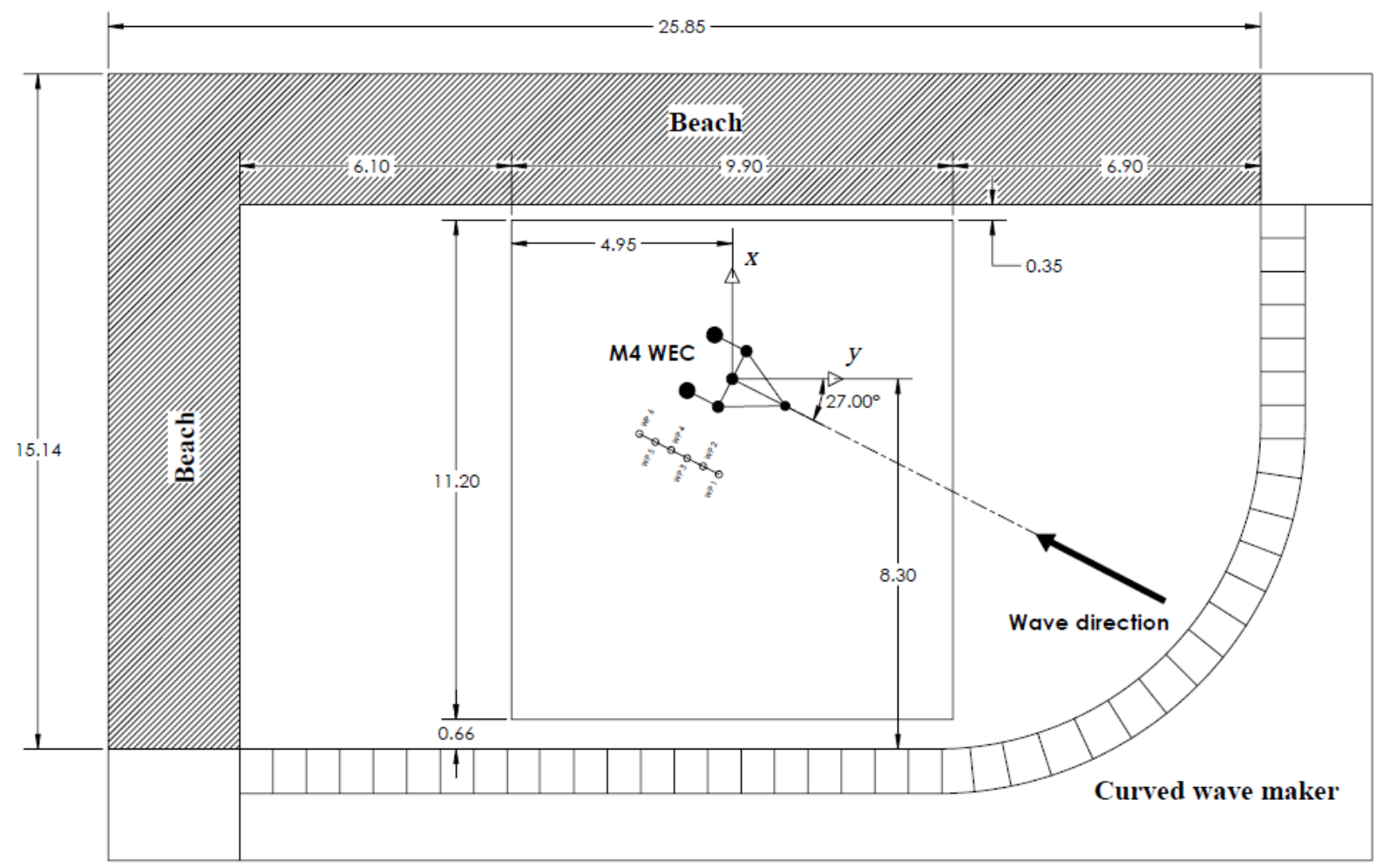

Fig. 1. Lir Ocean Basin, University College Cork, from diagram provided by UCC.

a)

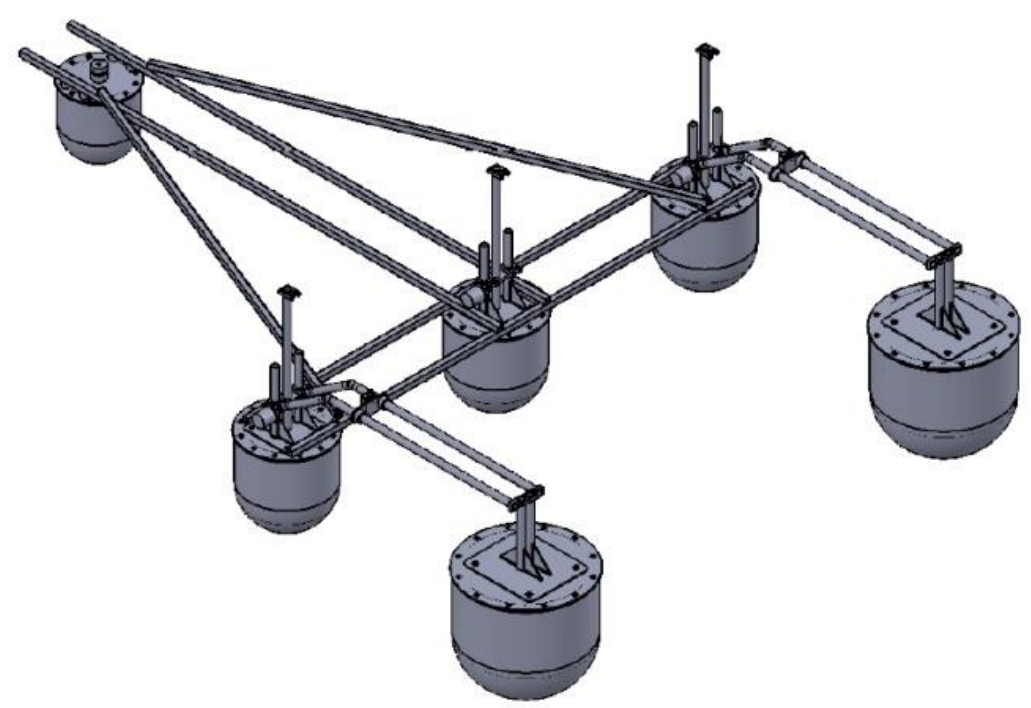


b)

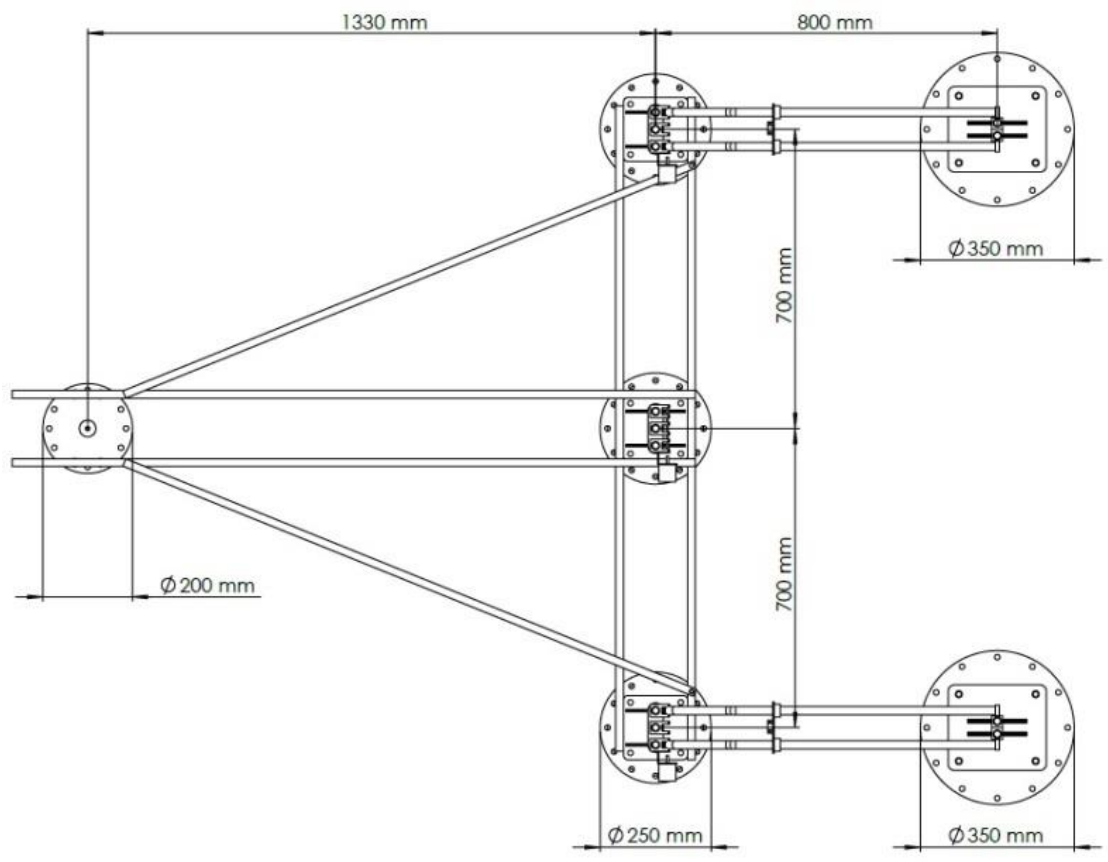

c)

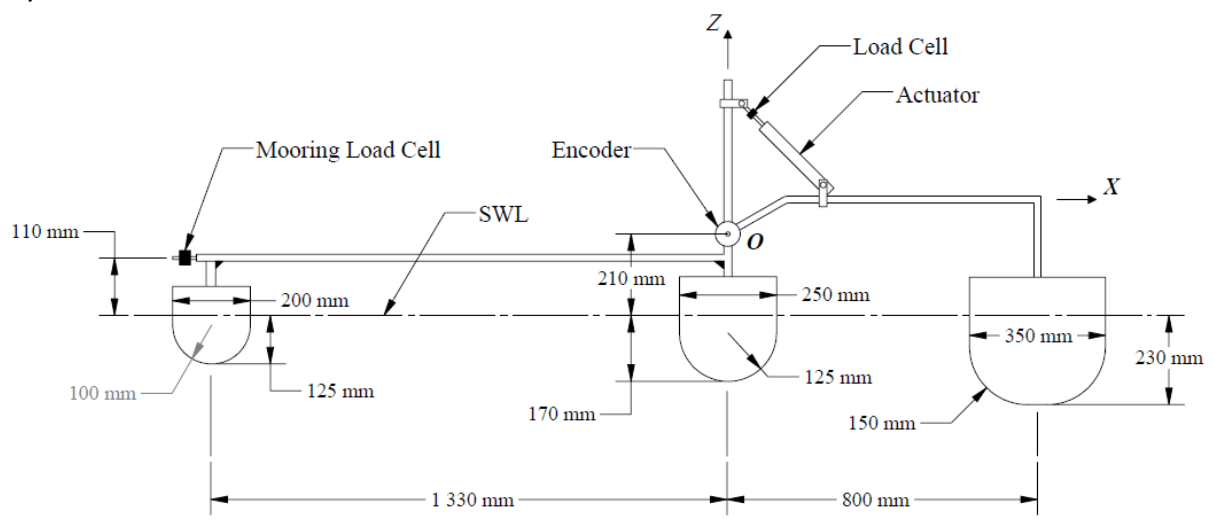

Fig. 2. WEC configuration : a) 3D view, b) plan dimensions, c) elevation dimensions.

Fig. 2c shows the position of the hinge and pneumatic cylinder damper (PTO). The upward kink on the stern beam is to avoid clashing on the mid floats in extreme wave tests. The relative angle between bow/mid floats and stern floats, $\theta$, was measured with a digital encoder and the force in the PTO was measured with a load cell. The moving cylinder geometry in relation to the hinge position gives the displacement and hence velocity in the cylinder which multiplied by force gives power. For the mathematical model the mechanical damping moment about the hinge is required and is given by $M_{d}=-B_{d} \dot{\theta}$ where $B_{d}$ is the damping coefficient determined by fitting the moment 
determined from measurement to the linear formula. The correlation $R^{2}>0.95$ always. An example plot of $M_{d}$ v. $\dot{\theta}$ and a sample of $M_{d}$ v. time is shown in Fig. 3 for $H_{s}=0.039 \mathrm{~m}$ and $T_{p}=1.2 \mathrm{~s}$.

a)

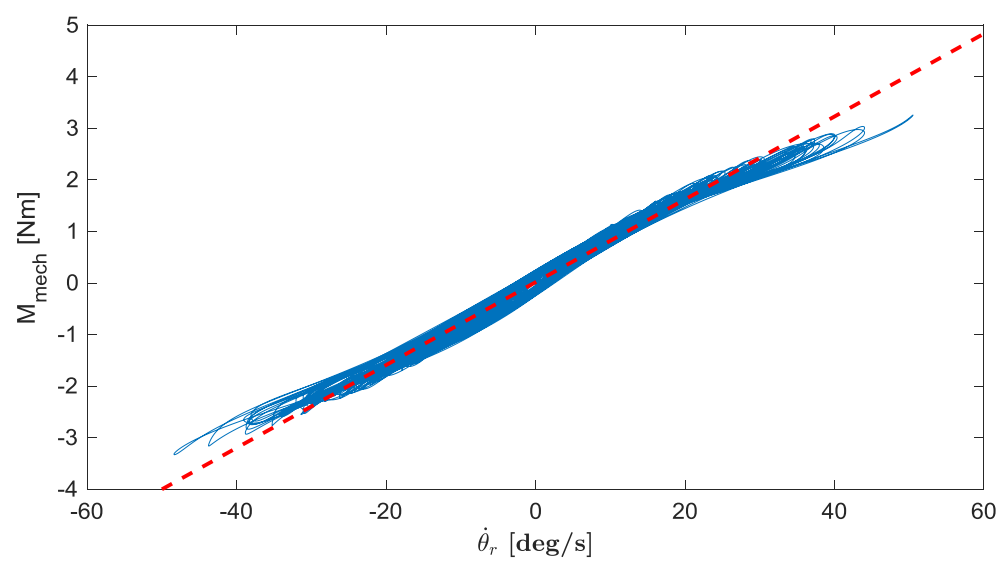

b)

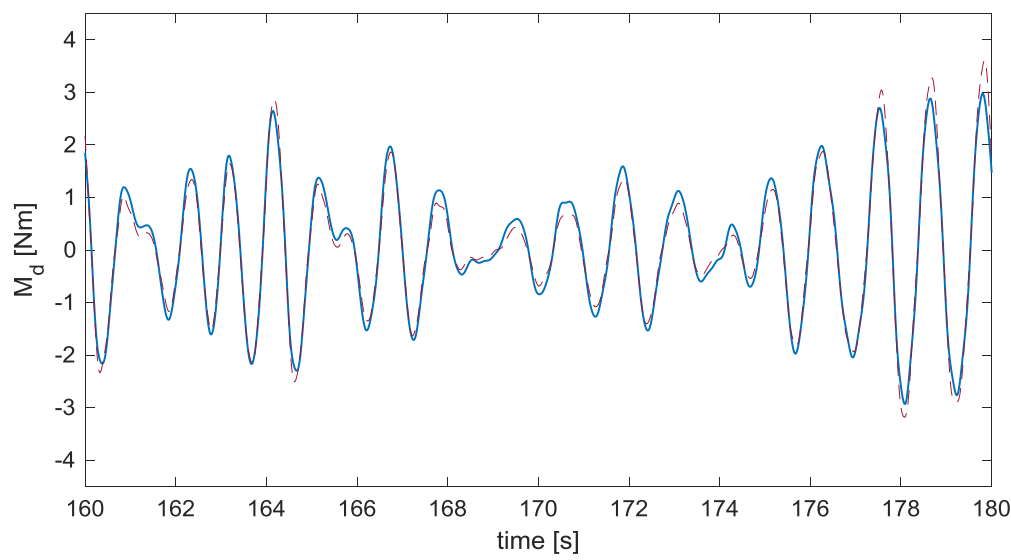

Fig.3 (a) Plot of $M_{d}$ v. $\dot{\theta}$ with dashed line showing linear fit and (b) a sample of $M_{d}$ v. time for $H_{s}=$ $0.039 \mathrm{~m}$ and $T_{p}=1.2 \mathrm{~s}$ with dashed line showing fit with $R^{2}=0.97$.

The damping coefficient could not be controlled but modelling indicates that power generation is only weakly dependent on its magnitude. The centreline elevation through the device with the mooring system is shown in Fig.4. The latter is quite simple with the focus on relative response and resulting power generation. The horizontal mooring (fairlead) force on the bow float was measured with a load cell. The mooring buoy was spherical, made from light plastic, with a diameter of $11 \mathrm{~cm}$ and mass of $87 \mathrm{~g}$. The mechanical multi-float system specification is defined in the Appendix. Table $A 1$ gives the masses and inertias and $A 2$ and $A 3$ the damping coefficients for each uni-directional wave condition with spectral peakedness factors $\gamma=1$ and 3.3 respectively. Damping coefficients 
for multi-directional cases are given in Table A4. Modelling indicates that maximum power is quite insensitive to $B_{d}$ with $6 \mathrm{Nms}$ giving good overall performance. The results shown are close to maximum and an example of optimising $B_{d}$ is discussed later. The time domain linear diffraction model for surge, pitch and heave float motions in uni-directional waves has been described in [12] and the measured surface elevation is input for each case although this was always close to the target spectrum in these tests. The model has been generalised to include sway and roll motion since the damping coefficient in each PTO was not equal (although cylinders had identical part number).

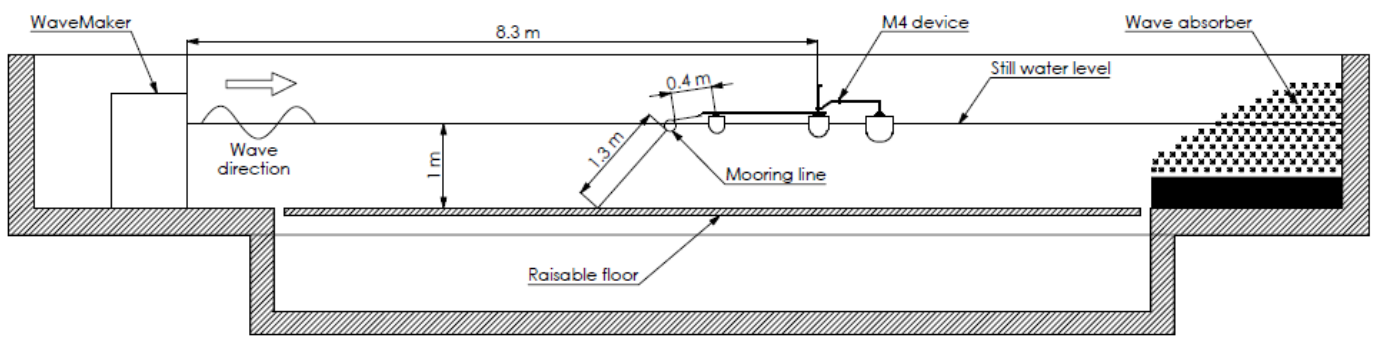

Fig.4 Elevation in the wave basin showing mooring configuration.

\section{Results}

\subsection{Operational conditions}

Results are presented for variation of relative angle $\theta$, average mechanical power $P_{a v}$ (the time average of power $P=-M_{d} \dot{\theta}$ ), and capture width with peak period $T_{p}$. Runs were generally $256 \mathrm{~s}$ long with $120 \mathrm{~s}$ between runs and averages were taken over $128 \mathrm{~s}$; averages over the first and second $128 \mathrm{~s}$ were almost identical. The maximum capture width for point absorbers and hinged rafts has been shown theoretically in regular waves to be proportional to wavelength $[13,14]$ and for the irregular waves of this study the capture width is normalised by the wavelength, $L_{e}$, for the energy period, $T_{e}$, calculated from the dispersion equation $\omega^{2}=g k \tanh (k d)$ where $d$ is depth, $g$ is gravitational acceleration and in this case $\omega=2 \pi / T_{e}$ and $k=2 \pi / L_{e}$. The normalised capture width, NCW, is thus equal to $\frac{P_{a v}}{P_{\text {wave }}} / L_{e}$ where $P_{\text {wave }}$ is the average rate of wave energy propagation per metre crest width given by $\int \frac{\rho g}{2} \frac{\omega}{k}\left(1+\frac{2 k d}{\sinh (2 k d)}\right) S(f) d f$ where $S(f)$ is spectral density, $f$ is frequency, $\omega=2 \pi f, k$ is wave number and $\rho$ is water density. Note the term normalised capture width is used to differentiate from capture width ratio which can be associated with capture width divided by body width. The NCW dependence on $T_{p}$ is a convenient performance characteristic which, combined with a scatter diagram for a given site, determines the annual energy yield.

In this 6-float case with two pneumatic dampers/PTOs the linear damping coefficient for each could differ by up to $50 \%$, although of identical type. This makes response and power from each slightly different. The results presented for $\theta$ and $P_{a v}$ are thus given for each damper and their combined power. The optimum power $P_{o p t}$ equal to twice the larger $P_{a v}$ is also presented. Results were obtained for $H_{s}=0.04$ and $0.06 \mathrm{~m}$ with $\gamma=1$ and 3.3 with uni-directional waves and with $H_{S}=0.04 \mathrm{~m}$ and $\gamma=1$ for directional spreading factor $s=20$ and 5 . The parameter $s$ defines a spreading function of cosine shape, $\cos ^{2 s}\left(\frac{\alpha}{2}\right)$ where $\alpha$ is angle relative to the predominant wave direction, as proposed by [15] following [16], and is standard in the OCEAN software of Edinburgh Designs[17]. Linear diffraction model results from the model of [12] are included for uni-directional waves $(s=\infty)$ using 
the damping constants fitted to the experimental results (from Tables A2 and A3). $H_{S}=0.04 \mathrm{~m}$ corresponds to about $2 \mathrm{~m}$ full scale which is a typical average value for western UK coasts.

Fig. 5 shows results for $\theta_{\text {rms }}$ v. $T_{p}$ with $\gamma=1$ for $H_{s}=0.04$ and $0.06 \mathrm{~m}$. There is a clear difference between port (left) and starboard (right) float motion. Fig. 6 shows corresponding results for $\theta_{\max } \mathrm{v}$. $T_{p}$. Agreement with linear model is closer for $H_{s}=0.04 \mathrm{~m}$ than $0.06 \mathrm{~m}$ as might be expected. Note that $\theta$ was limited to $15^{\circ}$ in the experiments which is seen to affect $\theta_{\text {max }}$ for $H_{s}=0.06 \mathrm{~m}$ in Fig.6. Fig.7 shows corresponding average powers $P_{a v}$ and there is again difference between port (left) and starboard (right) sides with power capture underestimated for smaller $T_{p}$. To account for asymmetric damping the linear diffraction model with roll and sway was run and both motions were shown to be very small. Fig. 8 shows corresponding results for NCW which will be used to determine energy yield. Fig. 9 shows results for mean and maximum mooring forces only for $H_{s}=0.06 \mathrm{~m}$; the load cell was damaged for $H_{s}=0.04 \mathrm{~m}$. Largest values occur when peak periods are close to those for largest angular motion. The maximum values are roughly an order of magnitude greater than the average.

Results are shown for $\gamma=3.3$ in Figs. 10,11, 12, 13 and 14. The response and power prediction by linear diffraction is similar to $\gamma=1$. In both cases the underestimation of power is greater for $H_{s}=0.06 \mathrm{~m}$ suggesting higher, probably $2^{\text {nd }}$, order effects might be significant. The mooring forces shown in Fig. 14 for $H_{s}=0.06 \mathrm{~m}$ are roughly twice those for $H_{s}=0.04 \mathrm{~m}$ suggesting $2^{\text {nd }}$ order dependence as might be expected. The maxima are again about an order of magnitude greater than the averages.

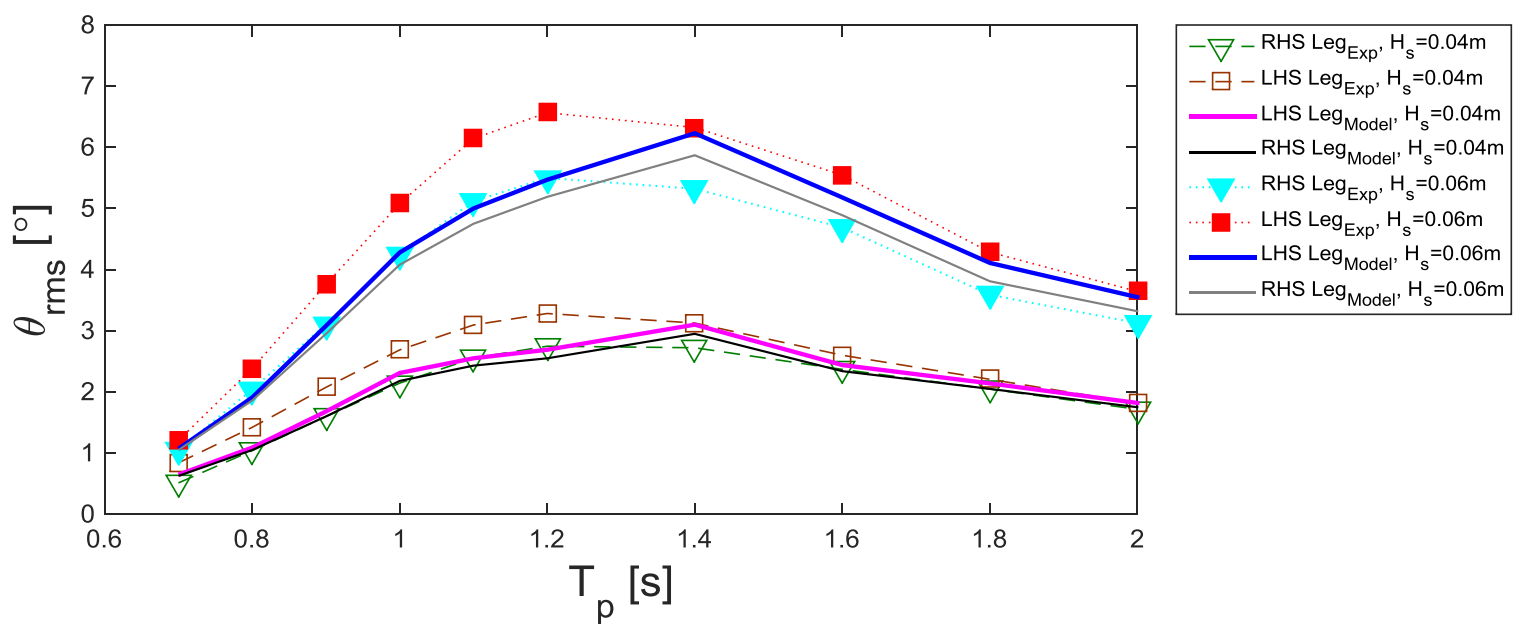

Fig.5 Variation of $\theta_{r m s}$ with $T_{p}$ for $\gamma=1.0: H_{s}=0.04 \mathrm{~m}$ and $H_{s}=0.06 \mathrm{~m}$ 


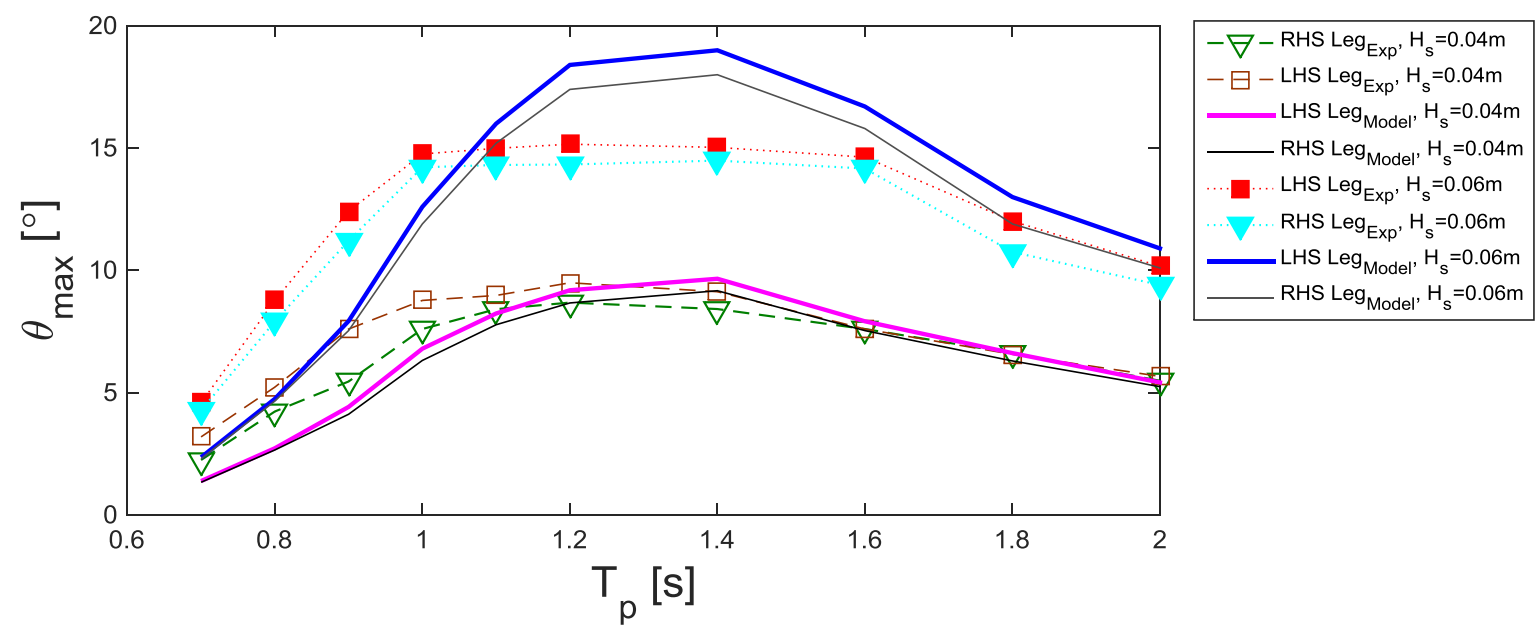

Fig. 6 Variation of $\theta_{\max }$ with $T_{p}$ for $\gamma=1.0: H_{s}=0.04 \mathrm{~m}$ and $H_{s}=0.06 \mathrm{~m}$.

a)

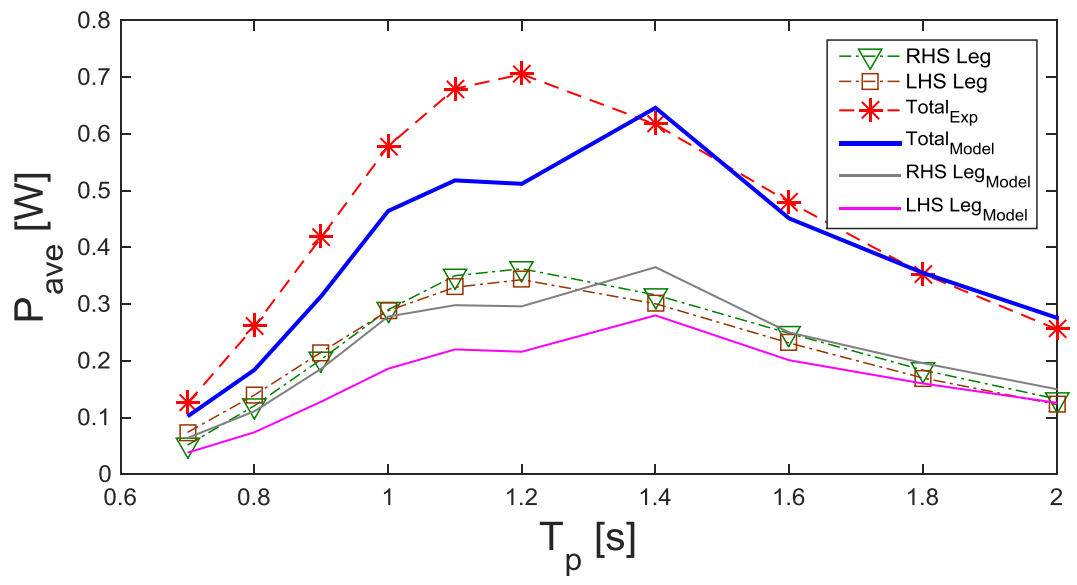

b)

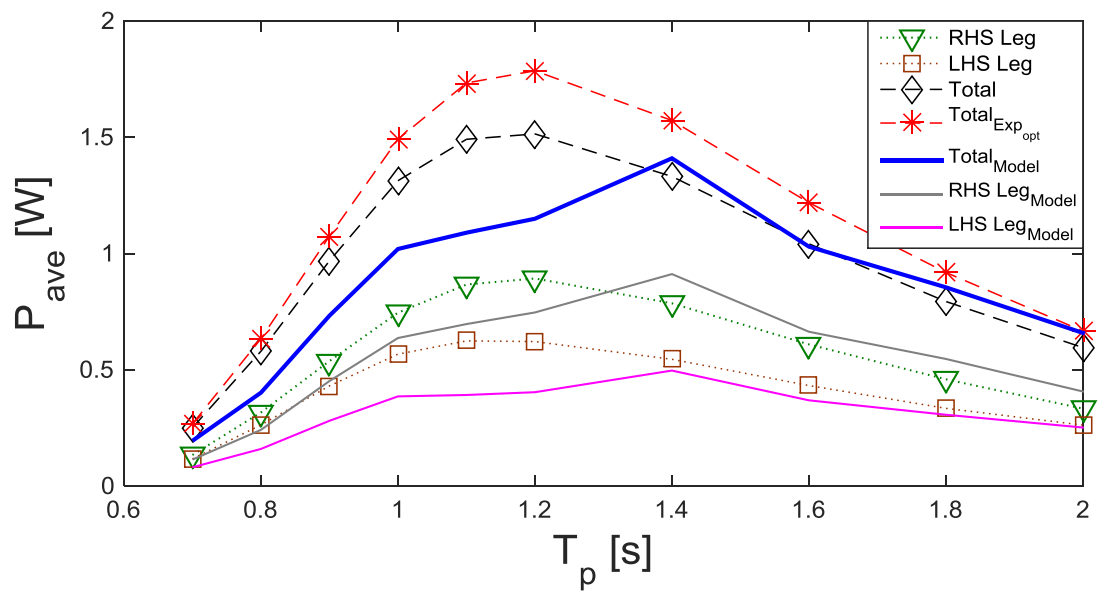

Fig.7 Variation of $P_{a v}$ with $T_{p}$ for $\mathrm{\gamma}=1.0:$ a) $H_{s}=0.04 \mathrm{~m}$, b) $H_{s}=0.06 \mathrm{~m}$ 
a)

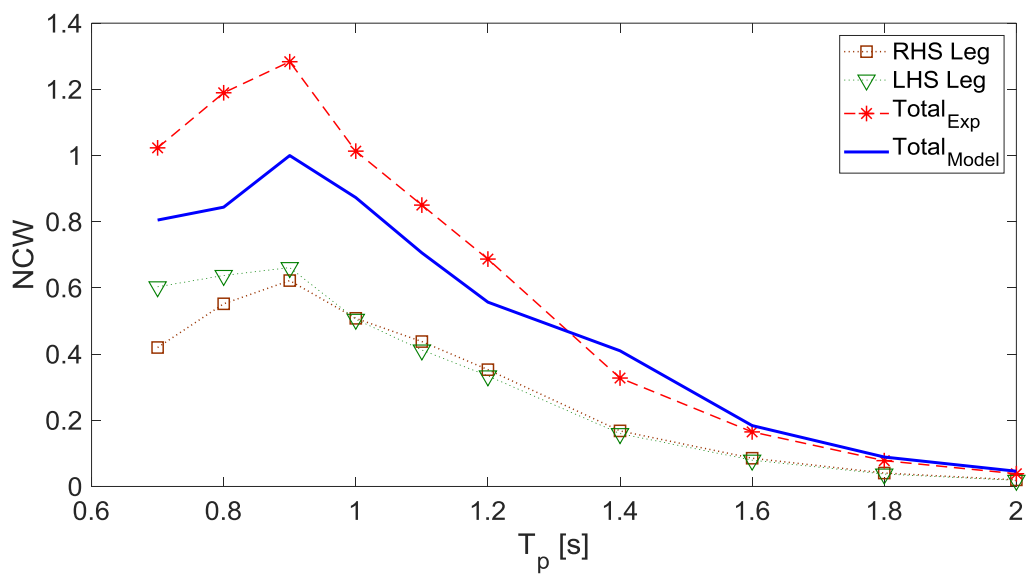

b)

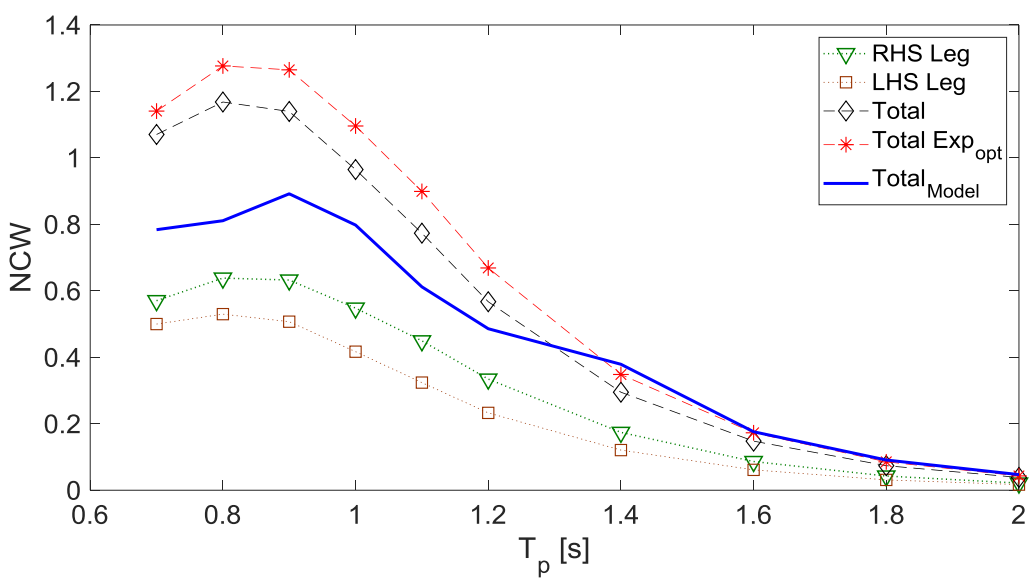

Fig.8 Variation of NCW with $T_{p}$ for $\gamma=1.0:$ a) $H_{s}=0.04 \mathrm{~m}$, b) $H_{s}=0.06 \mathrm{~m}$ 


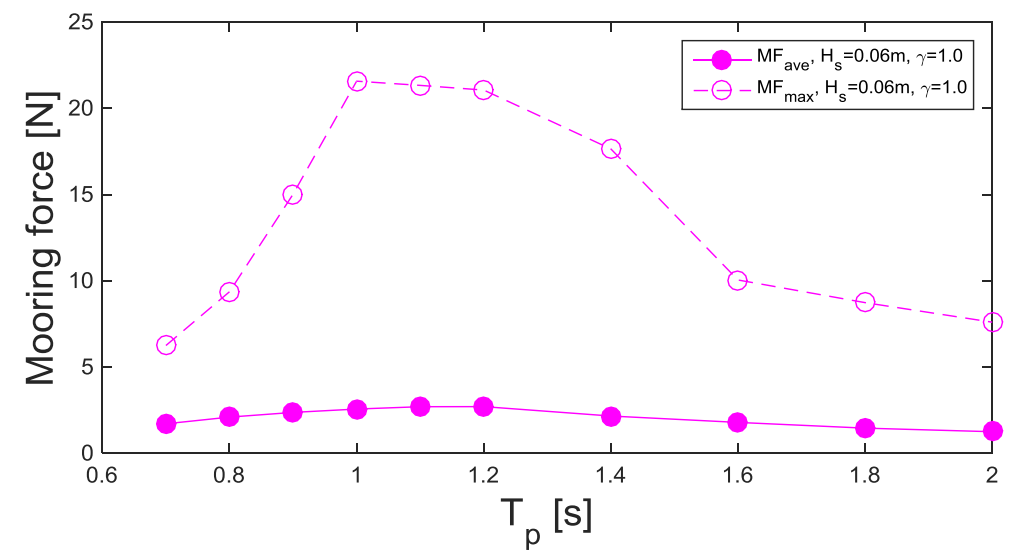

Fig.9 Variation of average and maximum mooring force with $T_{p}$ for $\psi=1: H_{s}=0.06 \mathrm{~m}$
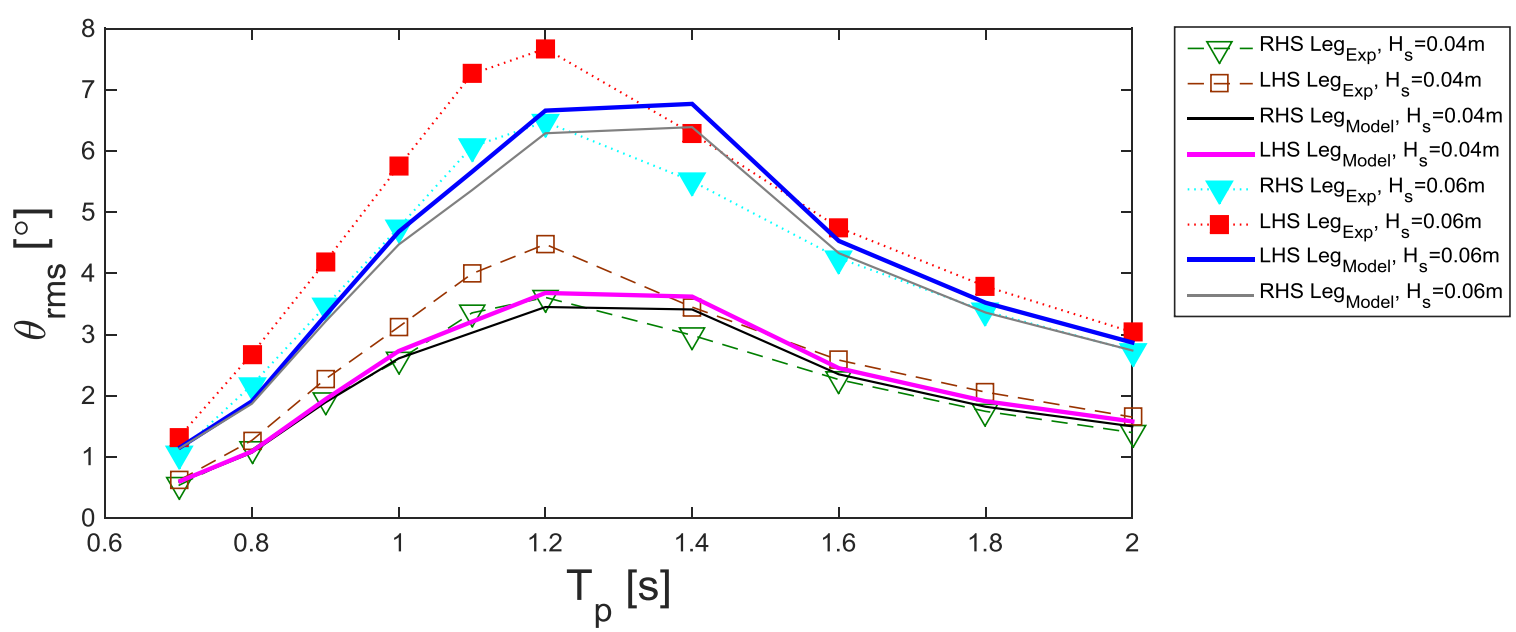

Fig.10 Variation of $\theta_{r m s}$ with $T_{p}$ for $\gamma=3.3: H_{s}=0.04 \mathrm{~m}$ and $H_{s}=0.06 \mathrm{~m}$

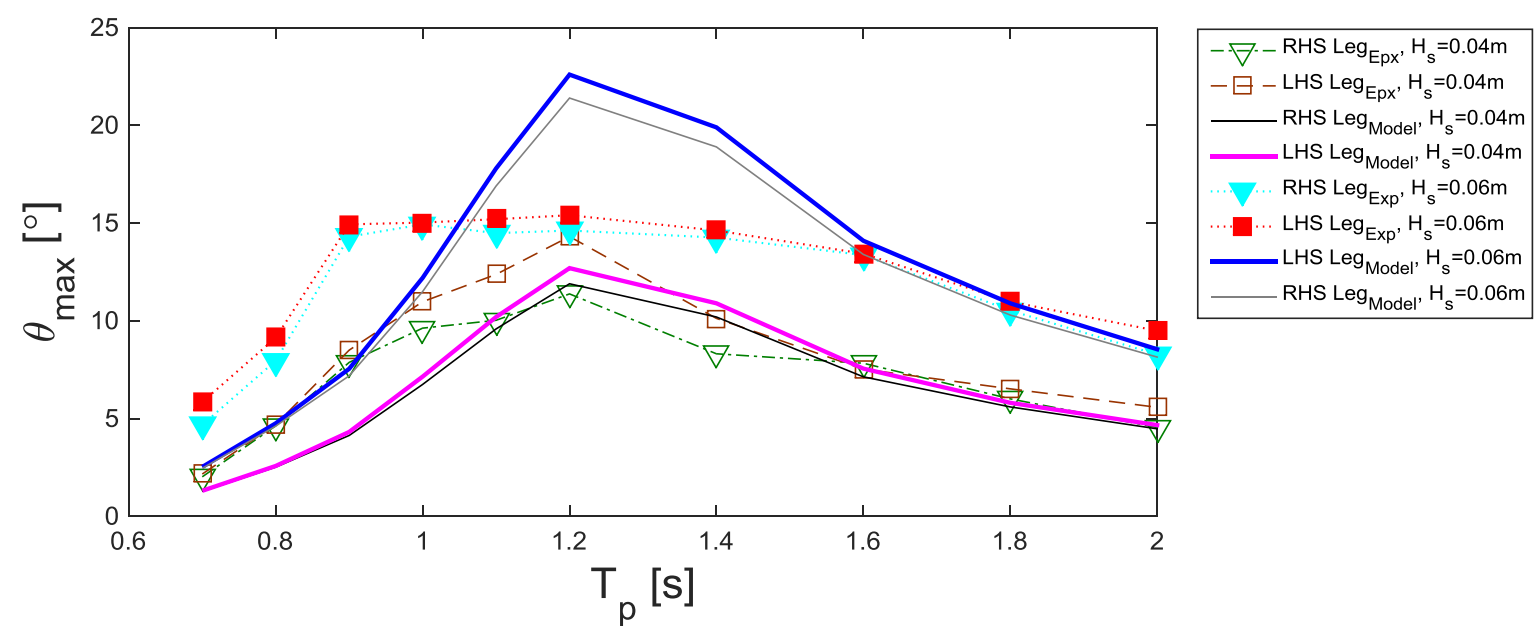

Fig.11 Variation of $\theta_{\max }$ with $T_{p}$ for $\gamma=3.3: H_{s}=0.04 \mathrm{~m}, H_{s}=0.06 \mathrm{~m}$. 
a)

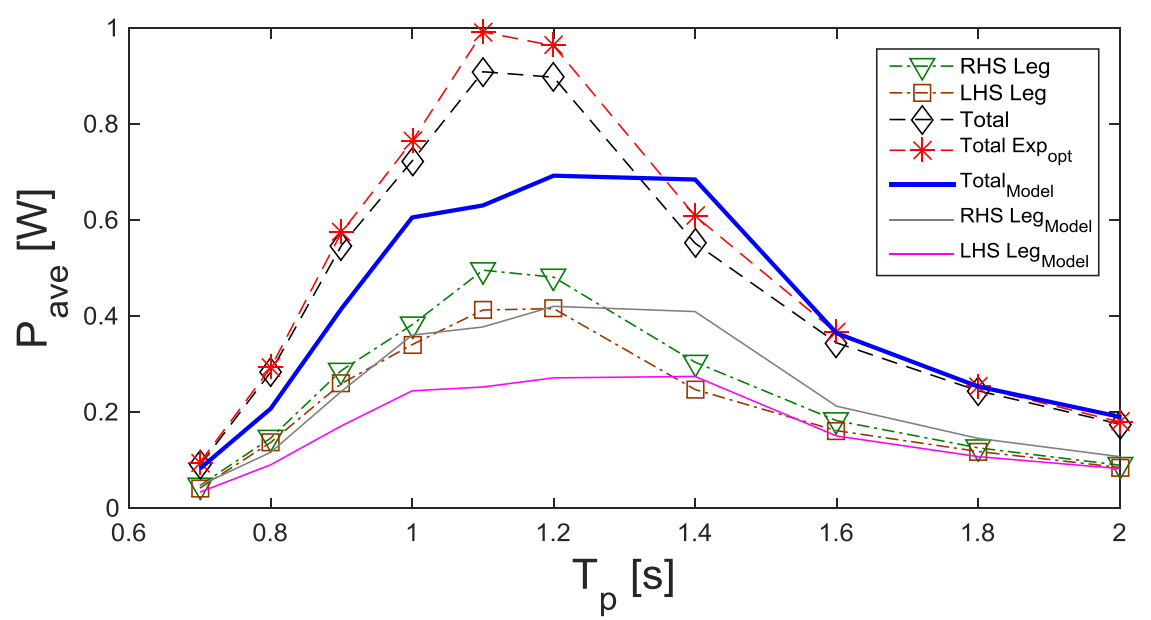

b)

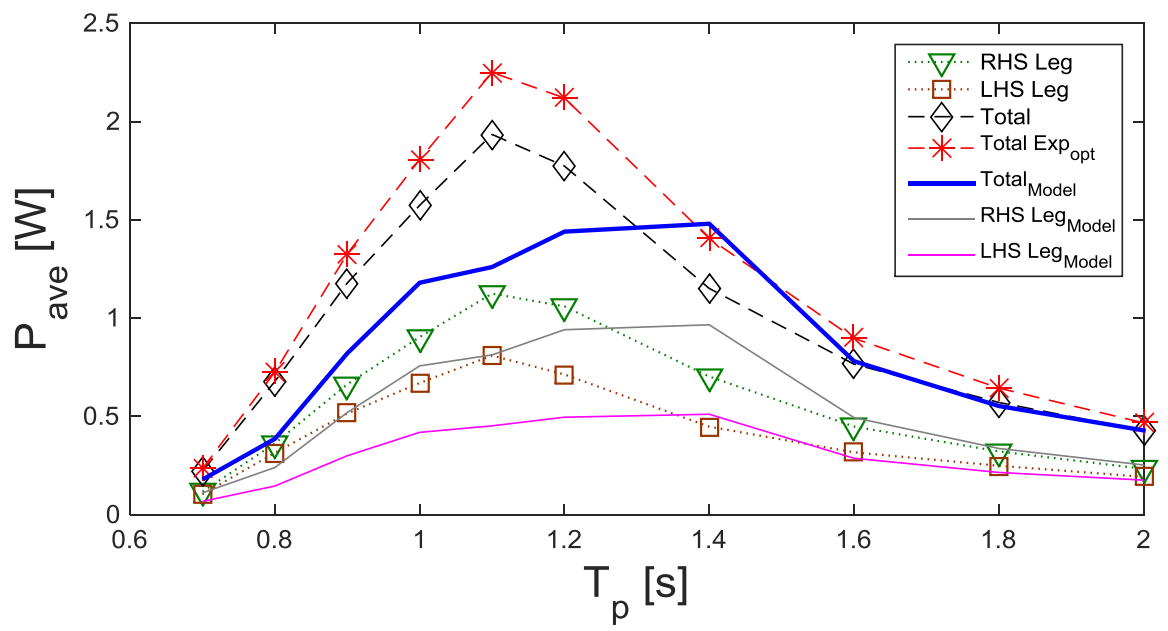

Fig.12 Variation of $P_{a v}$ with $T_{p}$ for $\gamma=3.3$ : a) $H_{s}=0.04 \mathrm{~m}$, b) $H_{s}=0.06 \mathrm{~m}$

a)

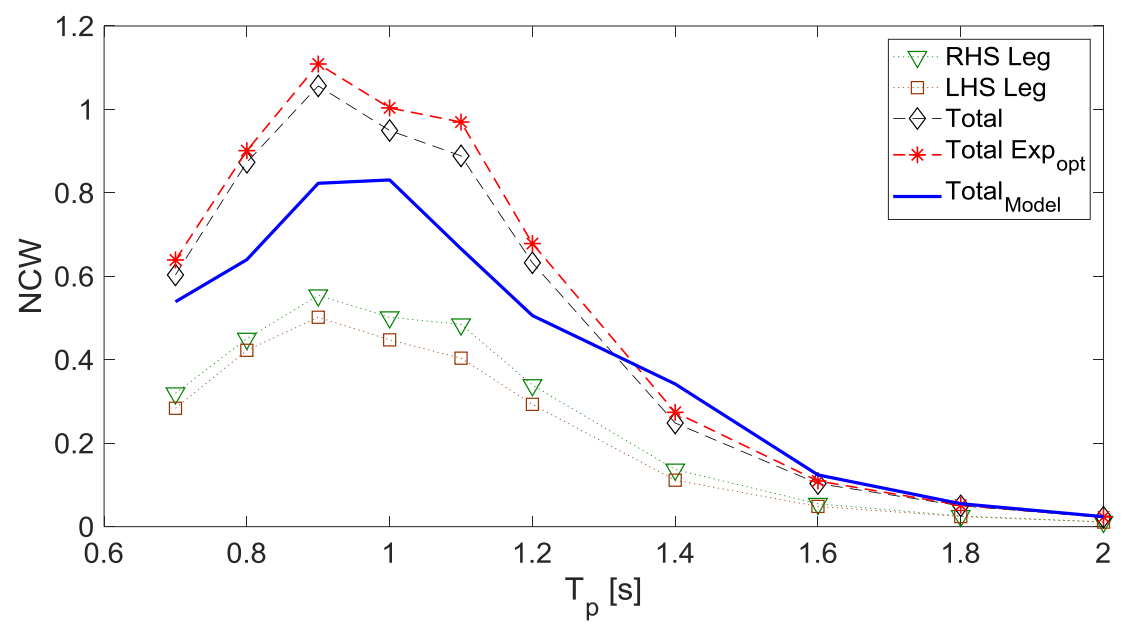


b)

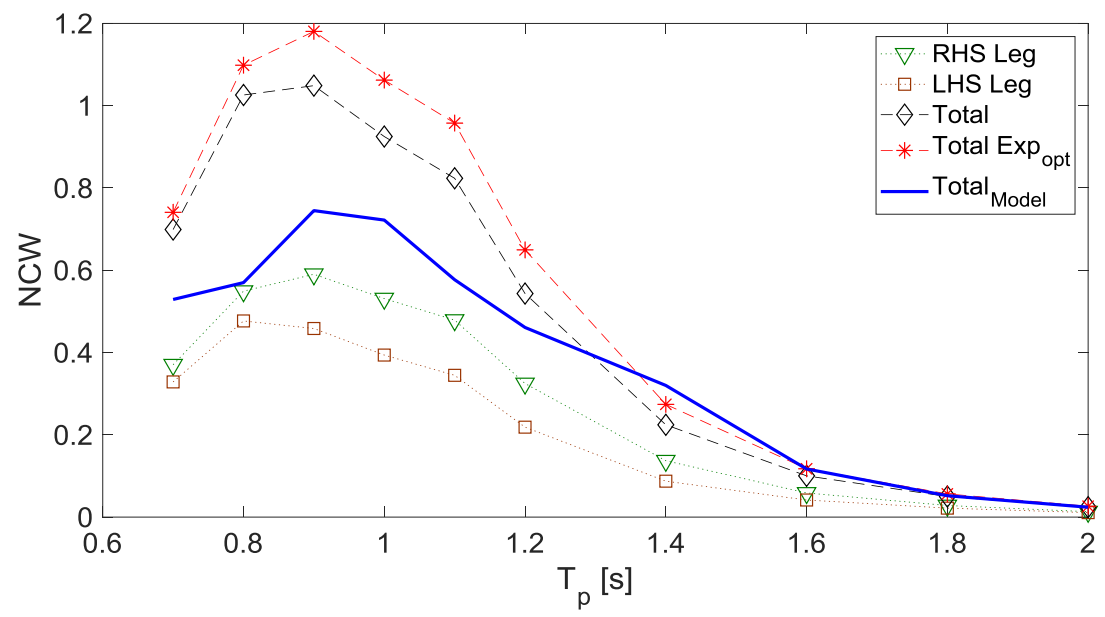

Fig. 13 Variation of NCW with $T_{p}$ for $\gamma=3.3:$ a) $H_{s}=0.04 \mathrm{~m}$, b) $H_{s}=0.06 \mathrm{~m}$

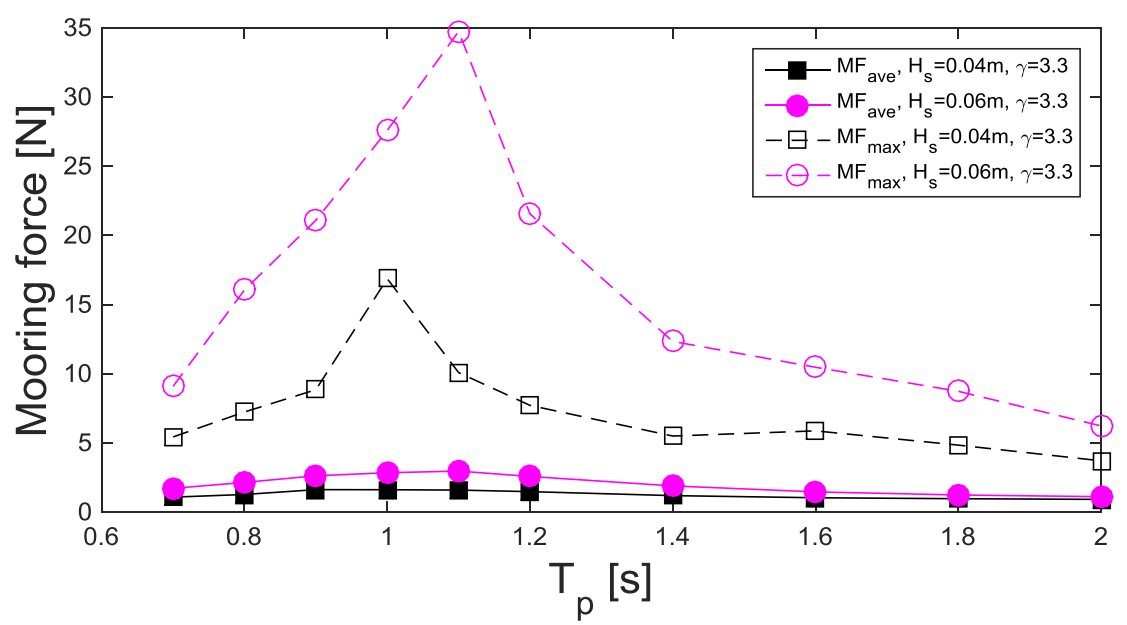

Fig.14 Variation of average and maximum mooring force with $T_{p}$ for $\gamma=3.3: H_{s}=0.04 \mathrm{~m}$ and $0.06 \mathrm{~m}$

All results for NCW are compiled in Fig. 15 including those with directional spreading for $H_{s}=0.04$ $\mathrm{m}$ and $\gamma=1$; NCW is effectively non-dimensional power. The magnitudes for uni-directional waves with $H_{s}=0.04 \mathrm{~m}$ and $0.06 \mathrm{~m}$ for $\gamma=1$ and 3.3 are close with magnitudes for $\gamma=3.3$ slightly smaller for lower $T_{p}<1 \mathrm{~s}$. However with directional spreading NCW magnitudes are somewhat reduced although similar for both $s=20$ and 5 . 


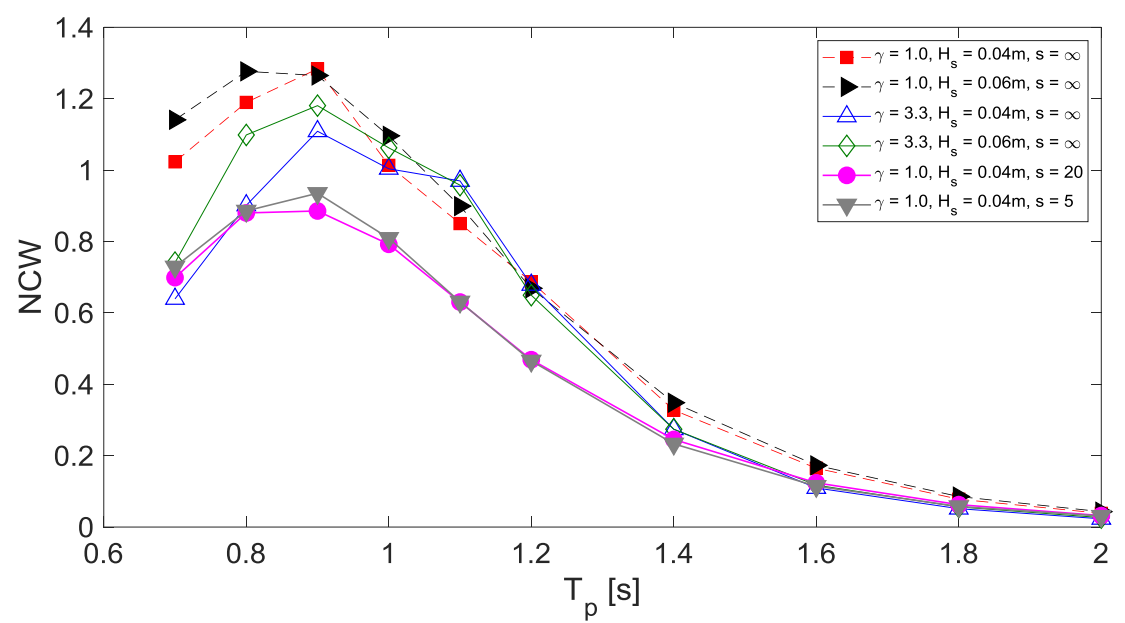

Fig.15 Variation of normalised capture width NCW with $T_{p}$ from experiments for all wave conditions: $H_{s}=0.04,0.06 \mathrm{~m} ; \mathrm{\gamma}=1,3.3 ; \mathrm{s}=\infty, 20,5$.

\subsection{Extreme conditions}

Without the PTO the variation of $\theta_{r m s}$ and $\theta_{\max }$ with $H_{s}$ is shown in Fig.16 for $T_{p}=1.0,1.4$ and $2.0 \mathrm{~s}$ with $\gamma=3.3$. These represent periods of about 7,10 and $14 \mathrm{~s}$ at full scale and $\gamma=3.3$ gives a narrow band spectrum often used for storm waves. Extreme waves generally have periods of about $10 \mathrm{~s}$ or more but $7 \mathrm{~s}$ is included since lower periods may cause large mooring forces. The largest wave heights for each period are the maximum possible in the Lir ocean basin. Both port (left) and starboard (right) sides are shown and values are very close as expected. The measured variations are close to linear with largest values for $T_{p}=1.4 \mathrm{~s}$ and $1.0 \mathrm{~s}$ and significantly less for $T_{p}=2.0 \mathrm{~s}$. Linear variations are consistent with analysis of focussed waves for the three-float device in Santo et al (2017). The linear diffraction model however overestimates for $T_{p}=1.4 \mathrm{~s}$, slightly underestimates for $T_{p}=1.0 \mathrm{~s}$ and is in close agreement for $T_{p}=2.0 \mathrm{~s}$.

a)

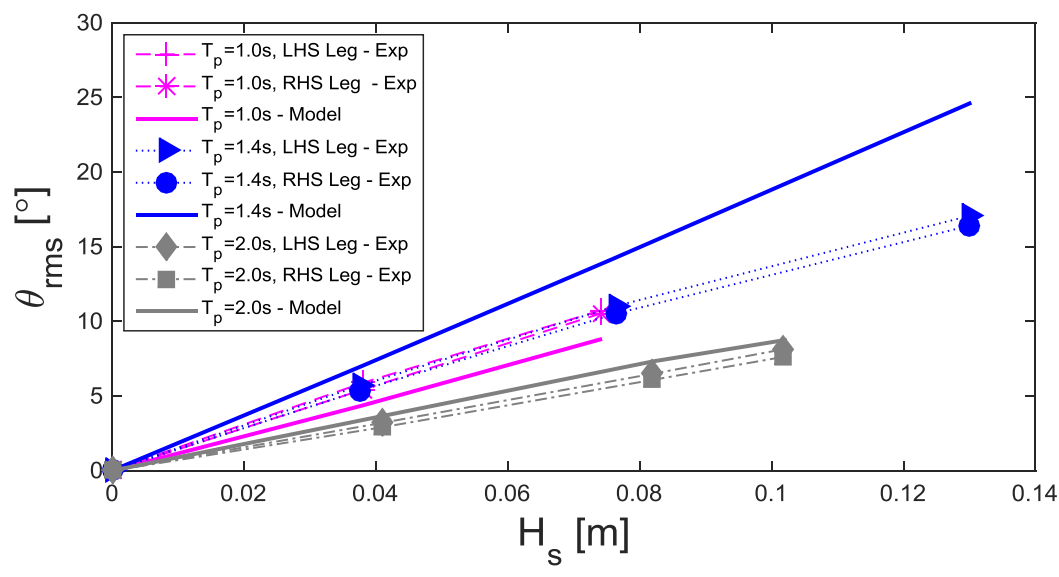


b)

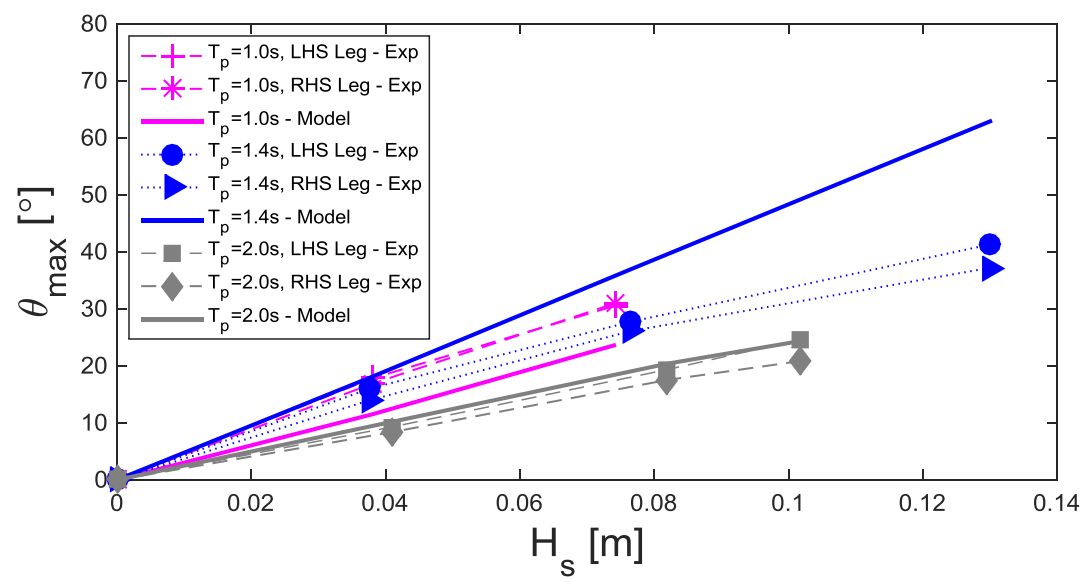

Fig.16 variation of a) $\theta_{r m s}$ and b) $\theta_{\max }$ with $H_{s}$ for $T_{p}=1.0,1.4,2.0 \mathrm{~s} ; \gamma=3.3$

The horizontal mooring (fairlead) force variation with $H_{S}$ is shown in Fig.17 giving average and maximum values. These are very small for $H_{s} \approx 0.04 \mathrm{~m}$, although slightly greater than with PTO engaged, increasing markedly for $H_{S} \approx 0.08 \mathrm{~m}$ and gradually increasing or decreasing slightly for further increase in $H_{s}$. Of course this will be affected by the mooring dynamics which is not analysed and the mooring design is only rudimentary. While mooring forces were roughly proportional to $H_{s}{ }^{2}$ for $H_{s}=0.04$ and $0.06 \mathrm{~m}$ with PTO engaged, this is clearly not the case for larger waves without the PTO engaged when forces have become large and increase slightly or not at all with $H_{s}$. The worst case appears with the two smaller periods which are clearly important for mooring design.

a)

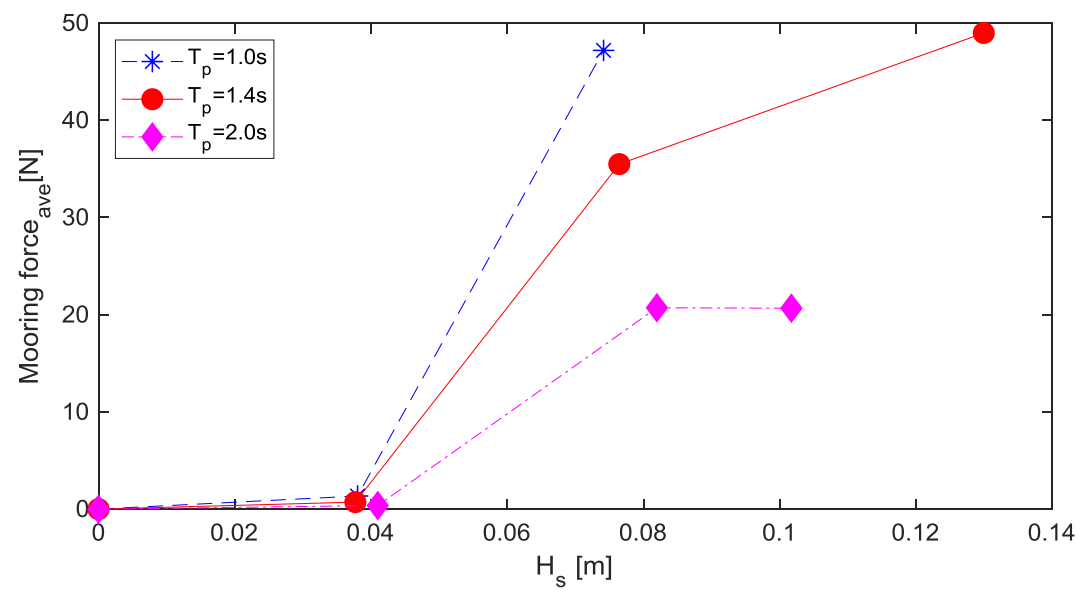


b)

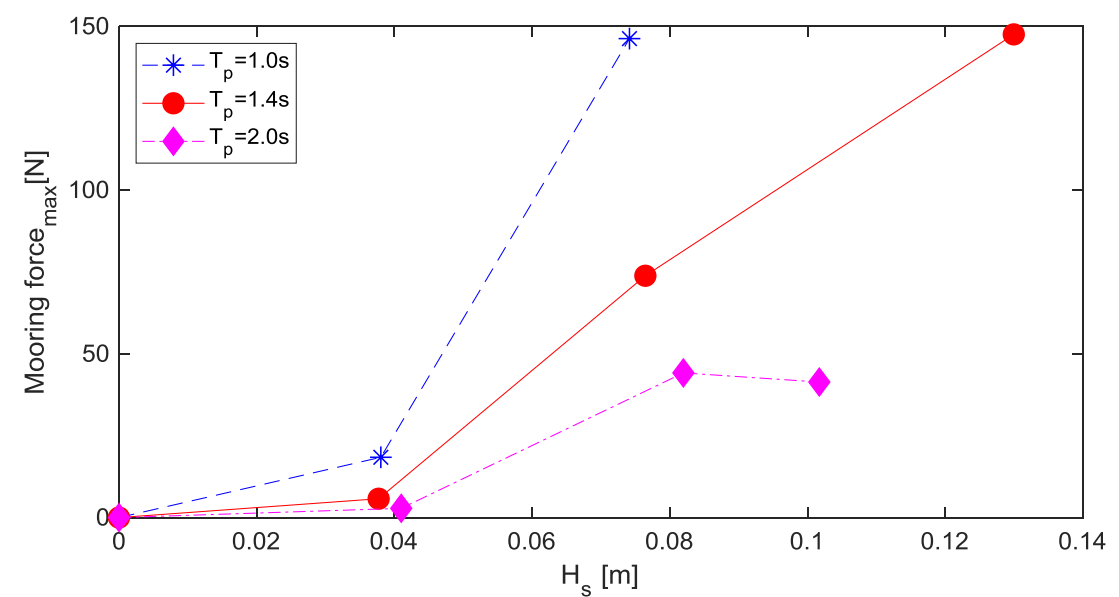

Fig.17 Variation of a) mean and b) maximum mooring force variation with $H_{s}$ for $T_{p}=1.0,1.4,2.0 \mathrm{~s}$; $\gamma=3.3$

\section{Energy yields and cost estimates}

Some energy yields and electricity cost estimates are made for eleven sites: in Tables 1-11 following the standard procedures in [12] which is now summarised. A given $T_{p}$ on a scatter diagram defines NCW for a particular $\gamma$ and spread factor $s$, as shown in Fig.15. $H_{s}$ from the scatter diagram, NCW, $L_{e}$ and $\gamma$ then determine average power for the 3 hour interval and hence energy. All values over a year are added to give the annual energy yield and equivalently the average annual power. Note NCW is slightly dependent on $H_{S}$ and results for model scale $H_{S}$ of $0.04 \mathrm{~m}$ and $0.06 \mathrm{~m}$ are included in the tables showing very slight dependence (for the same size device). The total cost is based on capital cost (CAPEX) with annual operation and maintenance costs (OPEX) $5 \%$ of CAPEX. The CAPEX involves all components: the prime mover (floats and beams), the PTO, anchorage, moorings, installation and grid connection. The structural cost of the prime mover is assumed to be $38 \%$ of the total (CAPEX) following Carbon Trust guidelines [18]. This cost is determined by the cost of steel assumed to be $£ 2000 /$ tonne based on 2016 UK construction rates for fabricated steel. The mass of steel is assumed to be proportional to the surface area of the floats with a constant thickness of 10 $\mathrm{mm}$. An earlier three-float device at a scale $5 \times$ the laboratory scale $[5,6]$ had a steel mass of 2.2 tonnes; this is used as a reference although ease of fabrication rather than efficient use of steel was the main consideration. This construction had flat bases. The area of steel sheet is determined and the mass of the equivalent 6 float configuration is proportional to the area of steel sheet. The thickness was $5 \mathrm{~mm}$ and full scale thickness is assumed to be $10 \mathrm{~mm}$. The mass at full scale is thus this mass times $2 x(L S F / 5)^{2}$ where LSF is the length scale factor of full scale in relation to the laboratory scale used in these tests. The cost of steel and hence CAPEX is thus obtained. Without structural optimisation this will be conservative. The widely used discounting approach [19] is used assuming a 20 years project life and a discount rate of $15 \%$ to give the levelised cost of electricity (LCOE). A machine efficiency of $85 \%$ and availability of $95 \%$ are assumed to be representative. The length scale factor (LSF) in Tables 1-11 is the value which gives minimum LCoE for each site and wave condition. Annual energy yield, annual average power supplied (both accounting for efficiency and availability), rated power set equal to $3 \times$ annual average power are given. Values for different wave 
conditions (spectral shape and directional spread) are provided, based on the NCW $v T_{p}$ curves from wave basin measurement.

Some observations are possible. With uni-directional waves narrower band spectra with $\gamma=3.3$ give larger energy yield (and lower LCoE) than broader band spectra with $\gamma=1$. Although the NCW $\vee T_{p}$ curves are very similar the energy period is smaller and wavelength smaller for $\gamma=1$ giving smaller power generation for a given $T_{p}$ and $H_{s}$ than for $\gamma=3$.3. Directional spreading reduces energy capture further although appears little affected by the degree of spreading. The reduction from narrow band uni-directional waves to directionally spread waves is about $40 \%$.

The very high energy wave sites, Belmullet and Death Coast, have high energy yields as expected although that for the medium energy site of Leixoes is similar to Belmullet which has a smaller average wave period; the size is also smaller and the LCoE for Belmullet has the smallest value of all sites considered. The other medium energy sites, Wavehub, Nova Scotia and California, have capacities in the 1-2 MW range. A detailed analysis of decadal energy yield, not considered here, for the NE Atlantic and North Sea is given in [20]. Sardinia is an example of an island state with a low wave climate and a high LCoE but this may be of interest since alternative sources are also high cost and wave energy machines have little environmental impact. Two small scale test sites are included: Fabtest and Galway Bay. Both are about half full scale based on this analysis of optimizing scale by LCoE but it is of interest to see what power capture may be expected.

The costs are proportional to the cost of steel and $£ 2000 /$ tonne may be conservative; $€ 1000 /$ tonne has been quoted by [21] and this would obviously more than halve the values of LCoE given in these tables. The relative magnitudes between sites and wave conditions are however likely to be representative.

Table 1 Energy yield and cost estimate for Wavehub test site at Cornwall, UK from [22]: average wave power $20 \mathrm{~kW} / \mathrm{m}$ at $37 \mathrm{~m}$ depth

\begin{tabular}{ccccccccc}
\hline Site & LSF & $\begin{array}{c}\text { Average } \\
\text { power } \\
\text { supply } \\
{[\mathrm{kW}]}\end{array}$ & $\begin{array}{c}\text { Annual } \\
\text { energy } \\
\text { yield } \\
{[\mathrm{MWh}]}\end{array}$ & $\begin{array}{c}\text { Rated } \\
\text { power } \\
\text { supply } \\
{[\mathrm{kW}]}\end{array}$ & $\begin{array}{c}\text { Cost/MW } \\
{[\mathrm{Mf} / \mathrm{MW}]}\end{array}$ & $\begin{array}{c}\text { Total } \\
\text { cost } \\
{[\mathrm{Mf}]}\end{array}$ & $\begin{array}{c}\text { LCoE } \\
{[\mathrm{f} / \mathrm{kWh}]}\end{array}$ & $\begin{array}{c}\text { Based on NCW for } \\
\text { laboratory wave conditions } \\
\text { with }\end{array}$ \\
\hline \multirow{2}{*}{$\begin{array}{c}\text { WaveHub, UK } \\
\text { Steel }\end{array}$} & 50 & 534 & 4677 & 1602 & 2.31 & 3.70 & 0.17 & $\gamma=1, H_{s}=.04 m, s=\infty$ \\
f2000/tonne & 50 & 392 & 3438 & 1177 & 3.14 & 3.70 & 0.23 & $\gamma=1, H_{s}=.04 m, s=20$ \\
& 50 & 548 & 4800 & 1644 & 3.24 & 5.33 & 0.23 & $\gamma=1, H_{s}=.04 m, s=5$ \\
& 50 & 645 & 5653 & 1935 & 1.91 & 3.70 & 0.14 & $\gamma=3.3, H_{s}=.04 m, s=\infty$ \\
& 50 & 651 & 5708 & 1954 & 1.89 & 3.70 & 0.14 & $\gamma=3.3, H_{s}=.06 m, s=\infty$ \\
\hline
\end{tabular}


Table 2 Energy yield and cost estimate for Belmullet, Ireland from [23]: average wave power $52 \mathrm{~kW} / \mathrm{m}$ at $150 \mathrm{~m}$ depth

\begin{tabular}{|c|c|c|c|c|c|c|c|c|}
\hline Site & LSF & $\begin{array}{c}\text { Average } \\
\text { power } \\
\text { supply } \\
{[\mathrm{kW}]}\end{array}$ & $\begin{array}{c}\text { Annual } \\
\text { energy } \\
\text { yield } \\
\text { [MWh] }\end{array}$ & $\begin{array}{c}\text { Rated } \\
\text { power } \\
\text { supply } \\
{[\mathrm{kW}]}\end{array}$ & $\begin{array}{l}\text { Cost/MW } \\
{[\mathrm{Mf} / \mathrm{MW}]}\end{array}$ & $\begin{array}{l}\text { Total } \\
\text { cost } \\
{[\mathrm{Mf}]}\end{array}$ & $\begin{array}{c}\text { LCoE } \\
{[£ / k W h]}\end{array}$ & $\begin{array}{c}\text { Based on NCW for } \\
\text { laboratory wave conditions } \\
\text { with }\end{array}$ \\
\hline \multirow{3}{*}{$\begin{array}{l}\text { Belmullet, } \\
\text { IRELAND }\end{array}$} & 80 & 2406 & 21077 & 7218 & 1.31 & 9.47 & 0.09 & $\gamma=1, H_{s}=.04 m, s=\infty$ \\
\hline & 70 & 1909 & 16722 & 5727 & 1.27 & 7.25 & 0.09 & $\gamma=1, H_{s}=.06 m, s=\infty$ \\
\hline & 70 & 1354 & 11861 & 4062 & 1.79 & 7.25 & 0.13 & $\gamma=1, H_{s}=.04 m, s=20$ \\
\hline \multirow{3}{*}{$\begin{array}{c}\text { Steel } \\
£ 2000 / \text { tonne }\end{array}$} & 70 & 1316 & 11535 & 3950 & 1.84 & 7.25 & 0.13 & $\gamma=1, H_{s}=.04 m, s=5$ \\
\hline & 70 & 2257 & 19777 & 6773 & 1.07 & 7.25 & 0.08 & $\gamma=3.3, H_{s}=.04 m, s=\infty$ \\
\hline & 70 & 2275 & 19936 & 6827 & 1.06 & 7.25 & 0.08 & $\gamma=3.3, H_{s}=.06 m, s=\infty$ \\
\hline
\end{tabular}

Table 3 Energy yield and cost estimate for FabTest site at Cornwall, UK from [22]: average wave power $4 \mathrm{~kW} / \mathrm{m}$ at $43 \mathrm{~m}$ depth

\begin{tabular}{ccccccccc}
\hline Site & LSF & $\begin{array}{c}\text { Average } \\
\text { power } \\
\text { supply } \\
{[\mathrm{kW}]}\end{array}$ & $\begin{array}{c}\text { Annual } \\
\text { energy } \\
\text { yield } \\
{[\mathrm{MWh}]}\end{array}$ & $\begin{array}{c}\text { Rated } \\
\text { power } \\
\text { supply } \\
{[\mathrm{kW}]}\end{array}$ & $\begin{array}{c}\text { Cost/MW } \\
{[\mathrm{Mf} / \mathrm{MW}]}\end{array}$ & $\begin{array}{c}\text { Total } \\
\text { cost } \\
{[\mathrm{Mf}]}\end{array}$ & $\begin{array}{c}\text { LCoE } \\
{[\mathrm{f} / \mathrm{kWh}]}\end{array}$ & $\begin{array}{c}\text { Based on NCW for } \\
\text { laboratory wave conditions } \\
\text { with }\end{array}$ \\
\hline \multirow{2}{*}{$\begin{array}{c}\text { FabTest, UK } \\
\text { Steel }\end{array}$} & 30 & 89 & 781 & 267 & 4.98 & 1.33 & 0.36 & $\gamma=1, H_{s}=.04 m, s=\infty$ \\
f2000/tonne & 30 & 65 & 568 & 195 & 6.85 & 1.33 & 0.49 & $\gamma=1, H_{s}=.04 m, s=20$ \\
& 30 & 64 & 559 & 191 & 6.96 & 1.33 & 0.50 & $\gamma=1, H_{s}=.04 m, s=5$ \\
& 30 & 104 & 914 & 313 & 4.26 & 1.33 & 0.31 & $\gamma=3.3, H_{s}=.04 m, s=\infty$ \\
& 30 & 106 & 932 & 319 & 4.17 & 1.33 & 0.30 & $\gamma=3.3, H_{s}=.06 m, s=\infty$ \\
\hline
\end{tabular}

Table 4 Energy yield and cost estimate for Sardinia, Italy from [24]: average wave power $10 \mathrm{~kW} / \mathrm{m}$ at $87 \mathrm{~m}$ depth

\begin{tabular}{cccccccccc}
\hline Site & LSF & $\begin{array}{c}\text { Average } \\
\text { power } \\
\text { supply } \\
{[\mathrm{kW}]}\end{array}$ & $\begin{array}{c}\text { Annual } \\
\text { energy } \\
\text { yield } \\
{[\mathrm{MWh}]}\end{array}$ & $\begin{array}{c}\text { Rated } \\
\text { power } \\
\text { supply } \\
{[\mathrm{kW}]}\end{array}$ & $\begin{array}{ccccc}\text { Cost/MW } \\
{[\mathrm{Mf} / \mathrm{MW}]}\end{array}$ & $\begin{array}{c}\text { Total } \\
\text { cost } \\
{[\mathrm{Mf}]}\end{array}$ & $\begin{array}{c}\text { LCoE } \\
{[\mathrm{f} / \mathrm{kWh}]}\end{array}$ & $\begin{array}{c}\text { Based on NCW for } \\
\text { laboratory wave conditions } \\
\text { with }\end{array}$ \\
\hline $\begin{array}{c}\text { Sardinia, } \\
\text { ITALY }\end{array}$ & 50 & 178 & 1561 & 535 & 6.92 & 3.70 & 0.50 & $\gamma=1, H_{s}=.04 m, s=\infty$ \\
Steel & 50 & 134 & 1616 & 553 & 6.69 & 3.70 & 0.48 & $\gamma=1, H_{s}=.06 m, s=\infty$ \\
f2000/tonne & 50 & 129 & 1132 & 388 & 9.55 & 3.70 & 0.69 & $\gamma=1, H_{s}=.04 m, s=5$ \\
& 50 & 205 & 1795 & 615 & 6.02 & 3.70 & 0.43 & $\gamma=3.3, H_{s}=.04 m, s=\infty$ \\
& 50 & 212 & 1857 & 636 & 5.82 & 3.70 & 0.42 & $\gamma=3.3, H_{s}=.06 m, s=\infty$ \\
\hline
\end{tabular}


Table 5 Energy yield and cost estimate for Death Coast, Spain, (location S5) from [25]; average wave power 50 $\mathrm{kW} / \mathrm{m}$ at $194 \mathrm{~m}$ depth

\begin{tabular}{ccccccccc}
\hline Site & LSF & $\begin{array}{c}\text { Average } \\
\text { power } \\
\text { supply } \\
{[\mathrm{kW}]}\end{array}$ & $\begin{array}{c}\text { Annual } \\
\text { energy } \\
\text { yield } \\
{[\mathrm{MWh}]}\end{array}$ & $\begin{array}{c}\text { Rated } \\
\text { power } \\
\text { supply } \\
{[\mathrm{kW}]}\end{array}$ & $\begin{array}{c}\text { Cost/MW } \\
{[\mathrm{Mf} / \mathrm{MW}]}\end{array}$ & $\begin{array}{c}\text { Total } \\
\text { cost } \\
{[\mathrm{Mf}]}\end{array}$ & $\begin{array}{c}\text { LCoE } \\
{[\mathrm{f} / \mathrm{kWh}]}\end{array}$ & $\begin{array}{c}\text { Based on NCW for } \\
\text { laboratory wave conditions } \\
\text { with }\end{array}$ \\
\hline $\begin{array}{c}\text { Death Coast, } \\
\text { SPAIN }\end{array}$ & 120 & 3738 & 32747 & 11215 & 1.90 & 21.31 & 0.14 & $\gamma=1, H_{s}=.04 m, s=\infty$ \\
$\begin{array}{c}\text { Steel } \\
\text { f2000/tonne }\end{array}$ & 120 & 2743 & 24031 & 8230 & 2.59 & 21.31 & 0.19 & $\gamma=1, H_{s}=.04 m, s=20$ \\
& 120 & 2679 & 23467 & 8037 & 2.65 & 21.31 & 0.19 & $\gamma=1, H_{s}=.04 m, s=5$ \\
& 110 & 3729 & 32664 & 11186 & 1.60 & 17.91 & 0.12 & $\gamma=3.3, H_{s}=.04 m, s=\infty$ \\
& 3789 & 33192 & 11367 & 1.58 & 17.91 & 0.11 & $\gamma=3.3, H_{s}=.06 m, s=\infty$ \\
\hline
\end{tabular}

Table 6 Energy yield and cost estimate for Death Coast, Spain, (location S8) from [25]; average wave power 49 $\mathrm{kW} / \mathrm{m}$ at $172 \mathrm{~m}$ depth

\begin{tabular}{cccccccccc}
\hline Site & LSF & $\begin{array}{c}\text { Average } \\
\text { power } \\
\text { supply } \\
{[\mathrm{kW}]}\end{array}$ & $\begin{array}{c}\text { Annual } \\
\text { energy } \\
\text { yield } \\
{[\mathrm{MWh}]}\end{array}$ & $\begin{array}{c}\text { Rated } \\
\text { power } \\
\text { supply } \\
{[\mathrm{kW}]}\end{array}$ & $\begin{array}{c}\text { Cost/MW } \\
{[\mathrm{Mf} / \mathrm{MW}]}\end{array}$ & $\begin{array}{c}\text { Total } \\
\text { cost } \\
{[\mathrm{Mf}]}\end{array}$ & $\begin{array}{c}\text { LCoE } \\
{[\mathrm{f} / \mathrm{kWh}]}\end{array}$ & $\begin{array}{c}\text { Based on NCW for } \\
\text { laboratory wave conditions } \\
\text { with }\end{array}$ \\
\hline $\begin{array}{c}\text { Death Coast, } \\
\text { SPAIN }\end{array}$ & 120 & 3760 & 32940 & 11281 & 1.89 & 21.31 & 0.14 & $\gamma=1, H_{s}=.04 m, s=\infty$ \\
Steel & 100 & 1927 & 16881 & 5781 & 2.56 & 14.80 & 0.18 & $\gamma=1, H_{s}=.04 m, s=20$ \\
f2000/tonne & 120 & 2698 & 23632 & 8093 & 2.63 & 21.31 & 0.19 & $\gamma=1, H_{s}=.04 m, s=5$ \\
& 110 & 3733 & 32698 & 11198 & 1.60 & 17.91 & 0.11 & $\gamma=3.3, H_{s}=.04 m, s=\infty$ \\
& 110 & 3800 & 33287 & 11400 & 1.57 & 17.91 & 0.11 & $\gamma=3.3, H_{s}=.06 m, s=\infty$ \\
\hline
\end{tabular}

Table 7 Energy yield and cost estimate for Galway Bay, Ireland from [26]; average wave power $1.7 \mathrm{~kW} / \mathrm{m}$ in 2010 at $25 \mathrm{~m}$ depth

\begin{tabular}{ccccccccc}
\hline Site & LSF & $\begin{array}{c}\text { Average } \\
\text { power } \\
\text { supply } \\
{[\mathrm{kW}]}\end{array}$ & $\begin{array}{c}\text { Annual } \\
\text { energy } \\
\text { yield } \\
{[\mathrm{MWh}]}\end{array}$ & $\begin{array}{c}\text { Rated } \\
\text { power } \\
\text { supply } \\
{[\mathrm{kW}]}\end{array}$ & $\begin{array}{c}\text { Cost/MW } \\
{[\mathrm{Mf} / \mathrm{MW}]}\end{array}$ & $\begin{array}{c}\text { Total } \\
\text { cost } \\
{[\mathrm{Mf}]}\end{array}$ & $\begin{array}{c}\text { LCoE } \\
{[\mathrm{f} / \mathrm{kWh}]}\end{array}$ & $\begin{array}{c}\text { Based on NCW for } \\
\text { laboratory wave conditions } \\
\text { with }\end{array}$ \\
\hline $\begin{array}{c}\text { Galway, } \\
\text { IRELAND }\end{array}$ & 30 & 24 & 206 & 71 & 18.85 & 1.33 & 1.35 & $\gamma=1, H_{s}=.04 m, s=\infty$ \\
Steel & 30 & 17 & 152 & 52 & 25.62 & 1.33 & 1.84 & $\gamma=1, H_{s}=.04 m, s=20$ \\
f2000/tonne & 30 & 17 & 149 & 51 & 26.03 & 1.33 & 1.87 & $\gamma=1, H_{s}=.04 m, s=5$ \\
& 20 & 12 & 106 & 36 & 16.34 & 0.59 & 1.17 & $\gamma=3.3, H_{s}=.04 m, s=\infty$ \\
& 20 & 12 & 109 & 37 & 15.85 & 0.59 & 1.14 & $\gamma=3.3, H_{s}=.06 m, s=\infty$ \\
\hline
\end{tabular}


Table 8 Energy yield and cost estimate for Portuguese Continental Coast (offshore site A1) from [27]: average wave power $26 \mathrm{~kW} / \mathrm{m}$ at $74 \mathrm{~m}$ depth

\begin{tabular}{|c|c|c|c|c|c|c|c|c|}
\hline Site & LSF & $\begin{array}{c}\text { Average } \\
\text { power } \\
\text { supply } \\
{[\mathrm{kW}]}\end{array}$ & $\begin{array}{c}\text { Annual } \\
\text { energy } \\
\text { yield } \\
\text { [MWh] }\end{array}$ & $\begin{array}{c}\text { Rated } \\
\text { power } \\
\text { supply } \\
{[\mathrm{kW}]}\end{array}$ & $\begin{array}{l}\text { Cost/MW } \\
{[\mathrm{Mf} / \mathrm{MW}]}\end{array}$ & $\begin{array}{l}\text { Total } \\
\text { cost } \\
{[\mathrm{Mf}]}\end{array}$ & $\begin{array}{c}\text { LCoE } \\
\text { [f/kWh] }\end{array}$ & $\begin{array}{c}\text { Based on NCW for } \\
\text { laboratory wave conditions with }\end{array}$ \\
\hline & 100 & 1841 & 16127 & 5523 & 2.68 & 14.80 & 0.19 & $\gamma=1, H_{s}=.04 m, s=\infty$ \\
\hline Leixoes, & 100 & 1895 & 16601 & 5685 & 2.60 & 14.80 & 0.19 & $\gamma=1, H_{s}=.06 m, s=\infty$ \\
\hline PORTUGAL & 100 & 1340 & 11737 & 4020 & 3.68 & 14.80 & 0.26 & $\gamma=1, H_{s}=.04 m, s=20$ \\
\hline \multirow{3}{*}{$\begin{array}{c}\text { Steel } \\
£ 2000 / \text { tonne }\end{array}$} & 110 & 1579 & 13829 & 4736 & 3.78 & 17.91 & 0.27 & $\gamma=1, H_{s}=.04 m, s=5$ \\
\hline & 100 & 2272 & 19902 & 6816 & 2.17 & 14.80 & 0.16 & $\gamma=3.3, H_{s}=.04 m, s=\infty$ \\
\hline & 100 & 2271 & 19897 & 6814 & 2.17 & 14.80 & 0.16 & $\gamma=3.3, H_{s}=.06 m, s=\infty$ \\
\hline
\end{tabular}

Table 9 Energy yield and cost estimate for Portuguese Continental Coast (nearshore site B16) from [27]: average wave power $25 \mathrm{~kW} / \mathrm{m}$ at $23 \mathrm{~m}$ depth

\begin{tabular}{|c|c|c|c|c|c|c|c|c|}
\hline Site & LSF & $\begin{array}{c}\text { Average } \\
\text { power } \\
\text { supply } \\
{[\mathrm{kW}]}\end{array}$ & $\begin{array}{c}\text { Annual } \\
\text { energy } \\
\text { yield } \\
\text { [MWh] }\end{array}$ & $\begin{array}{l}\text { Rated } \\
\text { power } \\
\text { supply } \\
{[\mathrm{kW}]}\end{array}$ & $\begin{array}{l}\text { Cost/MW } \\
{[\mathrm{Mf} / \mathrm{MW}]}\end{array}$ & $\begin{array}{l}\text { Total } \\
\text { cost } \\
{[\mathrm{Mf}]}\end{array}$ & $\begin{array}{c}\text { LCoE } \\
\text { [£/kWh] }\end{array}$ & $\begin{array}{l}\text { Based on NCW for } \\
\text { laboratory wave conditions with }\end{array}$ \\
\hline & 100 & 1385 & 12129 & 4154 & 3.56 & 14.80 & 0.26 & $\gamma=1, H_{s}=.04 m, s=\infty$ \\
\hline Leixoes, & 100 & 1430 & 12528 & 4290 & 3.45 & 14.80 & 0.25 & $\gamma=1, H_{s}=.06 m, s=\infty$ \\
\hline PORTUGAL & 100 & 1013 & 8871 & 3038 & 4.87 & 14.80 & 0.35 & $\gamma=1, H_{s}=.04 m, s=20$ \\
\hline \multirow{3}{*}{$\begin{array}{c}\text { Steel } \\
£ 2000 / \text { tonne }\end{array}$} & 110 & 1191 & 10434 & 3573 & 5.01 & 17.91 & 0.36 & $\gamma=1, H_{s}=.04 m, s=5$ \\
\hline & 100 & 1681 & 14724 & 5043 & 2.94 & 14.80 & 0.21 & $\gamma=3.3, H_{s}=.04 m, s=\infty$ \\
\hline & 100 & 1691 & 14813 & 5073 & 2.92 & 14.80 & 0.21 & $\gamma=3.3, H_{s}=.06 m, s=\infty$ \\
\hline
\end{tabular}

Table 10 Energy yield and cost estimate for Nova Scotia, Canada from [23]: average wave power $29 \mathrm{~kW} / \mathrm{m}$

\begin{tabular}{ccccccccc}
\hline Site & LSF & $\begin{array}{c}\text { Average } \\
\text { power } \\
\text { supply } \\
{[\mathrm{kW}]}\end{array}$ & $\begin{array}{c}\text { Annual } \\
\text { energy } \\
\text { yield } \\
{[\mathrm{MWh}]}\end{array}$ & $\begin{array}{c}\text { Rated } \\
\text { power } \\
\text { supply } \\
{[\mathrm{kW}]}\end{array}$ & $\begin{array}{c}\text { Cost/MW } \\
{[\mathrm{Mf} / \mathrm{MW}]}\end{array}$ & $\begin{array}{c}\text { Total } \\
\text { cost } \\
{[\mathrm{Mf}]}\end{array}$ & $\begin{array}{c}\text { LCoE } \\
{[\mathrm{f} / \mathrm{kWh}]}\end{array}$ & $\begin{array}{c}\text { Based on NCW for } \\
\text { laboratory wave conditions } \\
\text { with }\end{array}$ \\
\hline $\begin{array}{c}\text { Nova Scotia, } \\
\text { CANADA }\end{array}$ & 50 & 647 & 5670 & 1942 & 1.91 & 3.70 & 0.14 & $\gamma=1, H_{s}=.04 m, s=\infty$ \\
$\begin{array}{c}\text { Steel } \\
\text { f2000/ tonne }\end{array}$ & 50 & 476 & 4169 & 1428 & 2.59 & 3.70 & 0.19 & $\gamma=1, H_{s}=.04 m, s=20$ \\
& 50 & 465 & 4071 & 1394 & 2.65 & 3.70 & 0.19 & $\gamma=1, H_{s}=.04 m, s=5$ \\
& 50 & 802 & 7027 & 2407 & 1.54 & 3.70 & 0.11 & $\gamma=3.3, H_{s}=.04 m, s=\infty$ \\
& 50 & 7068 & 2421 & 1.53 & 3.70 & 0.11 & $\gamma=3.3, H_{s}=.06 m, s=\infty$ \\
\hline
\end{tabular}


Table 11 Energy yield and cost estimate for California, USA from [23]: average wave power $26 \mathrm{~kW} / \mathrm{m}$ at $213 \mathrm{~m}$ depth

\begin{tabular}{cccccccccc}
\hline Site & LSF & $\begin{array}{c}\text { Average } \\
\text { power } \\
\text { supply } \\
{[\mathrm{kW}]}\end{array}$ & $\begin{array}{c}\text { Annual } \\
\text { energy } \\
\text { yield } \\
{[\mathrm{MWh}]}\end{array}$ & $\begin{array}{c}\text { Rated } \\
\text { power } \\
\text { supply } \\
{[\mathrm{kW}]}\end{array}$ & $\begin{array}{ccccc}\text { Cost/MW } \\
{[\mathrm{Mf} / \mathrm{MW}]}\end{array}$ & $\begin{array}{c}\text { Total } \\
\text { cost } \\
{[\mathrm{Mf}]}\end{array}$ & $\begin{array}{c}\text { LCoE } \\
{[\mathrm{f} / \mathrm{kWh}]}\end{array}$ & $\begin{array}{c}\text { Based on NCW for } \\
\text { laboratory wave conditions } \\
\text { with }\end{array}$ \\
\hline $\begin{array}{c}\text { California, } \\
\text { USA }\end{array}$ & 70 & 1009 & 8836 & 3026 & 2.40 & 7.25 & 0.17 & $\gamma=1, H_{s}=.04 m, s=\infty$ \\
Steel & 70 & 740 & 6486 & 2221 & 3.26 & 7.25 & 0.23 & $\gamma=1, H_{s}=.04 m, s=20$ \\
f2000/tonne & 70 & 723 & 6329 & 2168 & 3.35 & 7.25 & 0.24 & $\gamma=1, H_{s}=.04 m, s=5$ \\
& 70 & 1247 & 10920 & 3740 & 1.94 & 7.25 & 0.14 & $\gamma=3.3, H_{s}=.04 m, s=\infty$ \\
& 70 & 10985 & 3762 & 1.93 & 7.25 & 0.14 & $\gamma=3.3, H_{s}=.06 m, s=\infty$ \\
\hline
\end{tabular}

\section{Discussion}

The number of floats in the multi-float M4 WEC has been increased to 8 through linear diffraction modelling and wave basin testing of the 6-float system with two PTOs has been analysed in this paper. The linear modelling was shown to slightly underestimate energy capture which was measured without the capability for optimisation of mechanical damping. While damping was closely linear for each irregular wave state the damping coefficient was not equal on both sides.

It is possible to modify the geometric configuration to increase energy capture using the linear diffraction model and an obvious possibility to reduce shielding of stern floats from bow and mid floats is to increase the lateral spacing of the stern floats. These positions were moved outwards laterally by $300 \mathrm{~mm}$ from those shown in Fig.2b. Results in Fig. 18 for $H_{s}=0.04 \mathrm{~m}$ and $\gamma=3.3$ show that power capture is increased slightly for the smaller periods using the experimental damping coefficients. It is also possible to optimise damping coefficient to maximise energy capture and results for average power and NCW are also shown in Fig.18. The optimum damping coefficient will of course also be dependent on $H_{S}$ but this is not considered. It can be seen that power is increased for the smaller periods, $T_{p}<1.4 \mathrm{~s}$, but for larger periods the physical damping was close to optimum. Optimising damping coefficient for a given sea state may be simply achieved through predetermined lookup tables and this is the simplest form of control. More sophisticated control (MPC or model predictive control) is being undertaken and preliminary results suggest that power capture may be increased by a further $50 \%$ [28]. This is all based on linear diffraction modelling which has been shown to underestimate power capture by about $15 \%$. Overall it seems likely that power estimates may be increased by a factor close to 2 . The basin tests have also shown that energy capture is dependent on the spectral shape and directionality of the wave conditions which is not generally taken into account. The LCOE is governed by the estimate for the cost of steel and lower estimates have been quoted. The relative cost between different wave conditions is however expected to be realistic. The capacity may be similar to offshore wind energy for certain sites with this 6-float system and this may be approximately doubled with the 8-float system which has 4 PTOs. 
a)

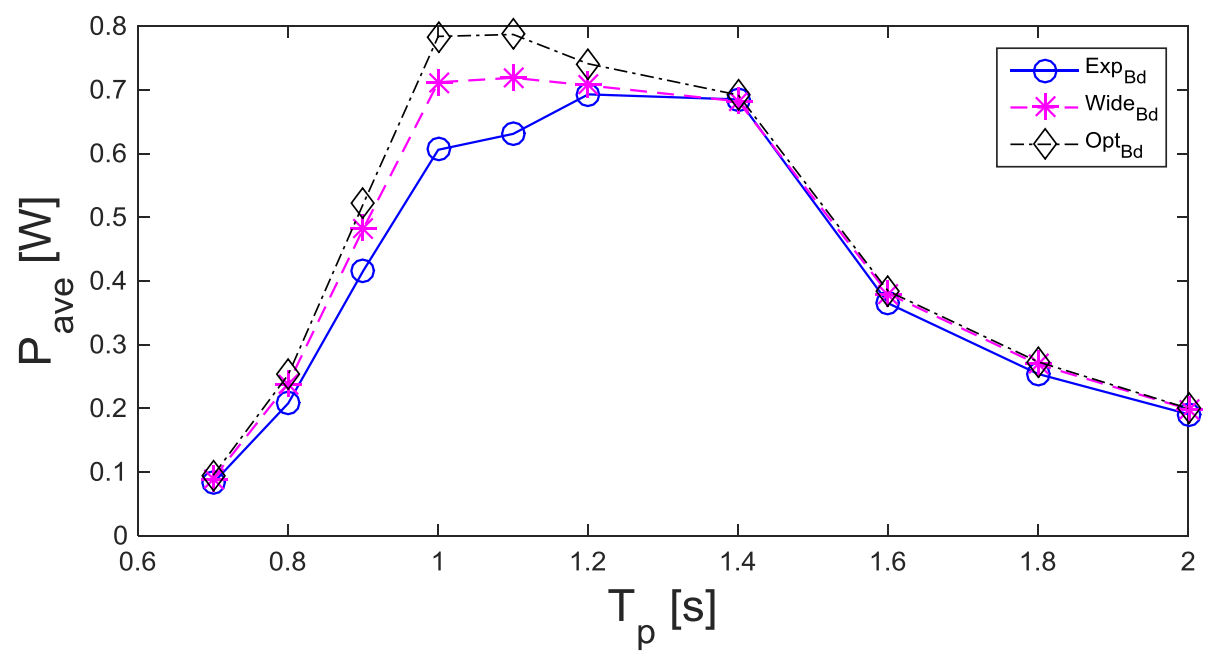

b)

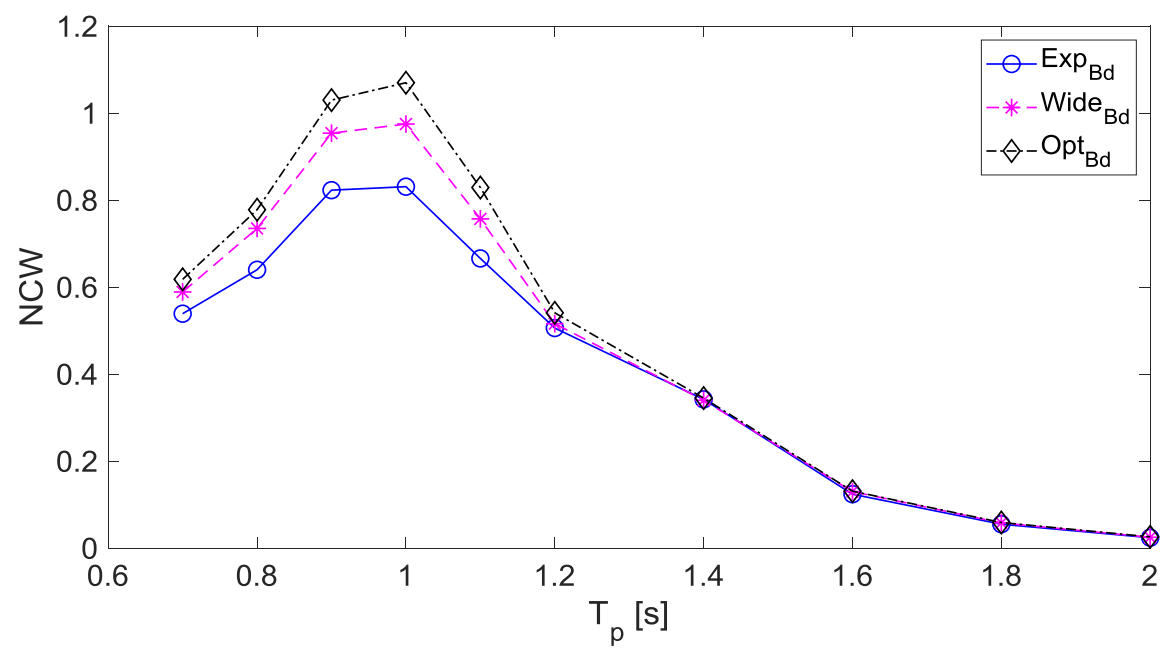

Fig.18 Variation of a) average power and b) NCW $v T_{p}$ from linear diffraction modelling based on damping coefficients $B_{d}$ measured experimentally, same $B_{d}$ with wider lateral stern spacing, with optimised $B_{d}$ for wider spacing, for $H_{s}=0.04 \mathrm{~m}$ and $\gamma=3.3$.

Without the PTOs engaged relative angular motion is seen to increase almost linearly with $H_{S}$ in keeping with earlier experimental analysis for the 3-float system in focussed waves [29] although the magnitude can be under or overestimated by linear diffraction theory. This is consistent with results in operational conditions where differences are thought to be due to $2^{\text {nd }}$ order effects and specifically partial trapping not evident with the 3-float device. However there may also be effects due to reflections in the basin. Although these are thought to be small with reflections less than $10 \%$ in an empty basin there has not been systematic analysis and of course with the device present there will be additional radiation effects which will also reflect within the basin. The linear diffraction model is presently available for uni-directional waves but it may be noted that the energy capture 
characteristics are close to those in the basin for multi-directional waves where any effects of reflection will be reduced when frequency and directionally averaged. In practice extreme angular motion may be restricted by deck submergence and associated sloshing or dunking and indeed the freeboard may be designed to achieve this, e.g. [30].

The mooring design is rudimentary as the focus of the tests was energy capture and relative angular motion. However the loads are qualitatively interesting with the largest magnitudes in extreme waves occurring in the range of wave periods of operational conditions .

\section{Conclusions}

The 6-float M4 configuration with two PTOs has been used to assess the results of the time domain linear diffraction analysis for multi-float configurations. In an ocean basin with small reflections (less than $10 \%$ in the working area) the linear model with uni-directional waves was shown to underestimate slightly power capture for operational conditions. The capture width, normalised by wavelength of energy period, could exceed unity and variation with peak period was very similar for spectral peakedness factors $\gamma$ of 1 and 3.3, and for significant wave heights of about $2 \mathrm{~m}$ and $3 \mathrm{~m}$ (full scale). With multi-directional waves with spreading factors $s=5$ and 20 energy capture is up to $40 \%$ less. Modifying the float spacing and geometry may improve energy capture and optimising the damping coefficient for each wave state further increased energy capture by about $10 \%$. Sophisticated control is being investigated and further increases of about $50 \%$ appear possible. There is clearly scope for combined optimisation of configuration and control, known as co-design. The capacity and LCoE could be similar to offshore wind energy for certain sites and with further optimisation LCOE could be generally similar or less. At full scale the capacity for each PTO would be about 1-2 MW and energy capture is approximately proportional to the number of PTOs. The extreme relative motion without the PTO engaged is approximately linear with wave height and may be limited by deck submergence or dunking by suitably designing float freeboard. While mooring design was somewhat rudimentary it would appear that greatest loads may occur in the range of wave periods of operational conditions.

\section{Acknowledgements}

Support through the EU Marinet2 programme and the Energy Sustainability Conayct-SENER fund provided by the Mexican government is gratefully acknowledged. Some results of this paper and diagrams are included in the proceedings of the 3rd International Conference on Renewable Energies Offshore, RENEW 2018, Lisbon. The reviewers made some helpful suggestions.

\section{References}

1. Cruz, J. 2008 Ocean wave energy, Springer, New York.

2. Falcão, A. F. de O. 2010 Wave energy utilization: A review of the technologies, Renewable and Sustainable Energy Reviews, 14, 899-918.

3. Retzler, C. 2006 Measurements of the slow drift dynamics of a model Pelamis wave energy converter, Renewable Energy, 31, 257-269. 
4. Moore, R., Murtagh, C., Elaesser, B. 2015 Design Optimisation of an Attenuator Wave Energy Converter, Proc EWTEC Nantes 2015.

5. Stansby, P., Carpintero Moreno, E., Stallard, T., Maggi, A. 2015a Three-float broad-band resonant line absorber with surge for wave energy conversion, Renewable Energy, 78, $132-140$

6. Stansby, P., Carpintero Moreno, E., Stallard, T., 2015b Capture width of the three-float multi-mode multi-resonance broad-band wave energy line absorber M4 from laboratory studies with irregular waves of different spectral shape and directional spread, J. Ocean Engineering and Marine Energy, 1(3), 287-298.

7. Sun, L., Stansby,P., Zang, J., Carpintero Moreno, E., Taylor, P. 2016 Linear diffraction analysis and optimisation of the three-float multi-mode wave energy converter M4 in regular waves including small arrays, J. Ocean Engineering and Marine Energy, 2(4), 429438.

8. Sun, L., Zang, J., Stansby,P., Carpintero Moreno, E., Taylor, P., Eatock Taylor, R. 2017 Linear diffraction analysis of the three-float multi-mode wave energy converter M4 for power capture and structural analysis in irregular waves with experimental validation, $\mathrm{J}$. Ocean Eng. Mar. Energy, 3(1), 51-68.

9. Eatock Taylor, R., Taylor, P.H. and Stansby, P.K. 2016 A coupled hydrodynamic-structural model of the M4 wave energy converter, J. Fluids and Struct. 63, 77-96.

10. Gu,H., Stansby,P., Stallard,T., Carpintero Moreno,E. 2018 Drag, added mass and radiation damping of oscillating vertical cylindrical bodies in heave and surge in still water, J. Fluids Struct, 82, 343-356.

11. Stansby, P.K., Carpintero Moreno, E. \& Stallard, T. 2016. Modelling of the 3-float WEC M4 with nonlinear PTO options and longer bow beam, Proc. 2nd Int. Conf. on Renewable Energies Offshore, Lisbon (RENEW 2016).

12. Stansby, P., Carpintero Moreno, E., Stallard, T., 2017 Large capacity multi-float configurations for the wave energy converter M4 using a time-domain linear diffraction model, Applied Ocean Research, 68, 53-64.

13. Falnes, J. 2002. Ocean waves and oscillating systems. Cambridge: Cambridge University Press.

14. Newman, J.N. 1979 Absorption of wave energy by elongated bodies. Applied Ocean Research, 1(4), 189-196.

15. Borgman, L.E. 1969 Directional spectral models for design use. In: Proceedings of Offshore Tech. Conf., Houston, Paper No. OTC 1069, pp 721-746.

16. Longuet-Higgins M.S., Cartwight,D.E. and Smith, N.D. 1963 Observations of the directional spectra of sea waves using the motions of a floating buoy, Ocean Wave Spectra, Prentice_Hall, 111-136.

17. www4.edesign.co.uk/product/wave-generating-software, accessed 15/11/2018

18. Carbon Trust 2012. Technology Innovation Need Assessment (TINA): Marine Energy, summary report. London. UK.

19. Stallard, T., Ricci, P., Dhedin, J-F., Harrison, G., Johanning, L. 2011 Economic Assessment of Marine Energy Projects. Chapter III in: Smith, G.H. et al. (eds.). The EQUIMAR Protocols. The Institute for Energy Systems. 
20. Santo,H., Taylor,P.H., Eatock Taylor,R., Stansby, P. 2016 Decadal variability of wave power production in the North-East Atlantic and North Sea for the M4 machine, Renewable Energy 91, 442-450.

21. Myhr,A., Bjerkseter, C., Ågotnes,A, Nygaard,T.A. 2014 Levelised cost of energy for offshore floating wind turbines in a life cycle perspective, Renewable Energy, 66, 714728.

22. Van Nieuwkoop, J.C., Smith, H.C., Smith, G.H., Johanning, L. 2013 Wave resource assessment along the Cornish coast (UK) from a 23-year hindcast dataset validated against buoy measurements. Renewable Energy, 58,1-14.

23. Dalton, G.J., Alcorn, R., Lewis, T. 2010 Case study feasibility analysis of the Pelamis wave energy convertor in Ireland, Portugal and North America, Renewable Energy. 35(2), 443455.

24. Vicinanza, D., Contestabile, P., Ferrante, V. 2013 Wave energy potential in the northwest of Sardinia (Italy), Renewable Energy, 50, 506-21.

25. Iglesias, G., Carballo, R. 2009 Wave energy potential along the Death Coast (Spain). Energy, 34(11), 1963-1975.

26. Atan, R., Goggins, J., Harnett, M., Agostinho, P., Nash, S. 2016 Assessment of wave characteristics and resource variability at a 1/4-scale wave energy test site in Galway Bay using waverider and high frequency radar (CODAR) data, Ocean Eng., 117, 272-291.

27. Silva, D., Rusu, E. and Guedes Soares, C. 2013 Evaluation of Various Technologies for Wave Energy Conversion in the Portuguese Nearshore, Energies, 6, 1344-1364.

28. Liao,Z., Gai,N., Stansby,P., Li,G. 2018 Control-Oriented Modelling of Wave Energy Converter M4, Proc 4th AWTEC, Taipei, Taiwan 2018.

29. Santo,H., Taylor, P.H., Carpintero Moreno, E., Stansby,P., Eatock Taylor, R., Sun,L., Zang,J, 2017 Extreme motion and response statistics for survival of the three-float wave energy converter M4 in intermediate water depth, J. Fluid Mech., 81, 175-204.

30. Stallard, T.J., Weller, S.D., Stansby, P.K. 2009 Limiting heave response of a wave energy device by draft adjustment with upper surface. Applied Ocean Research, 31(4), 282-289.

Appendix: Wave basin test parameters

\begin{tabular}{|c|c|c|c|c|c|c|}
\hline & Mass $[\mathrm{kg}]$ & $x_{q}[\mathrm{~m}]$ & $y_{a}[\mathrm{~m}]$ & $z_{q}[\mathrm{~m}]$ & $I_{x x}\left[\mathrm{kgm}^{2}\right]$ & $I_{\nu v}\left[\mathrm{kgm}^{2}\right]$ \\
\hline Bow float & 1.465 & -1.356 & 0 & -0.181 & 0.062 & 2.761 \\
\hline Bow/mid beams & 2.467 & -0.456 & 0 & -0.071 & 0.292 & 1.069 \\
\hline Mid float port & 2.845 & -0.026 & 0.705 & -0.160 & 1.547 & 0.132 \\
\hline Ballast & 2.700 & -0.027 & 0.710 & -0.321 & 1.609 & 0.288 \\
\hline Mid float centre & 2.845 & -0.026 & 0.005 & -0.160 & 0.131 & 0.132 \\
\hline Ballast & 2.700 & -0.027 & 0 & -0.321 & 0.286 & 0.288 \\
\hline Mid float right & 2.845 & -0.026 & -0.694 & -0.160 & 1.505 & 0.132 \\
\hline Ballast & 2.700 & -0.027 & -0.699 & -0.321 & 1.609 & 0.288 \\
\hline Beams mid/stern & 0.525 & 0.328 & \pm 0.697 & 0.087 & 0.261 & 0.090 \\
\hline Stern floats & 4.041 & 0.772 & \pm 0.700 & -0.204 & 2.248 & 2.680 \\
\hline Ballast & 13.000 & 0.772 & \pm 0.700 & -0.350 & 8.050 & 9.438 \\
\hline
\end{tabular}

Table A1 Mass of each component with centre of mass and inertia relative to hinge 0 . 


\begin{tabular}{|c|c|c|c|c|c|c|}
\hline$\gamma=1, \mathrm{~s}=\infty$ & \multicolumn{3}{|c|}{$H_{s} \approx 0.04 m$} & \multicolumn{3}{c|}{$H_{s} \approx 0.06 m$} \\
\hline $\begin{array}{c}T_{p} \\
(s)\end{array}$ & $\begin{array}{c}H_{s} \\
(m)\end{array}$ & $\begin{array}{c}B_{d, \text { starboard }} \\
(\mathrm{Nms})\end{array}$ & $\begin{array}{c}B_{d, \text { port }} \\
(\mathrm{Nms})\end{array}$ & $\begin{array}{c}H_{s} \\
(\mathrm{~m})\end{array}$ & $\begin{array}{c}B_{d, \text { starboard }} \\
(\mathrm{Nms})\end{array}$ & $\begin{array}{c}B_{d, \text { port }} \\
(\mathrm{Nms})\end{array}$ \\
\hline 0.70 & 0.028 & 8.305 & 5.354 & 0.039 & 5.422 & 4.377 \\
\hline 0.80 & 0.031 & 5.838 & 4.248 & 0.046 & 4.122 & 3.033 \\
\hline 0.90 & 0.031 & 4.828 & 3.554 & 0.051 & 3.447 & 2.320 \\
\hline 1.00 & 0.035 & 4.283 & 3.164 & 0.055 & 2.876 & 1.861 \\
\hline 1.10 & 0.036 & 4.027 & 3.005 & 0.056 & 2.526 & 1.505 \\
\hline 1.20 & 0.036 & 3.913 & 3.008 & 0.057 & 2.418 & 1.377 \\
\hline 1.40 & 0.037 & 3.940 & 3.185 & 0.058 & 2.502 & 1.410 \\
\hline 1.60 & 0.037 & 4.453 & 3.822 & 0.058 & 2.694 & 1.552 \\
\hline 1.80 & 0.038 & 4.692 & 4.090 & 0.059 & 3.758 & 2.095 \\
\hline 2.00 & 0.040 & 5.124 & 4.613 & 0.061 & 3.786 & 2.364 \\
\hline
\end{tabular}

Table A2 $B_{d}$ values (port and starboard sides) for uni-directional waves $(\mathrm{s}=\infty)$ with $\gamma=1$ and $H_{S} \approx 0.04,0.06 m$

\begin{tabular}{|c|c|c|c|c|c|c|}
\hline$\gamma=3.3, s=\infty$ & \multicolumn{3}{|c|}{$H_{s} \approx 0.04 m$} & \multicolumn{3}{c|}{$H_{s} \approx 0.06 m$} \\
\hline $\begin{array}{c}T_{p} \\
(s)\end{array}$ & $\begin{array}{c}H_{s} \\
(m)\end{array}$ & $\begin{array}{c}B_{d, \text { starboard }}(\mathrm{Nms}) \\
B_{d, \text { port }} \\
(\mathrm{Nms})\end{array}$ & $\begin{array}{c}H_{s} \\
(\mathrm{~m})\end{array}$ & $\begin{array}{c}B_{d, \text { starboard }} \\
(\mathrm{Nms})\end{array}$ & $\begin{array}{c}B_{d, \text { port }} \\
(\mathrm{Nms})\end{array}$ \\
\hline 0.70 & 0.029 & 8.337 & 6.743 & 0.042 & 8.516 & 7.683 \\
\hline 0.80 & 0.035 & 7.465 & 6.908 & 0.049 & 6.284 & 6.056 \\
\hline 0.90 & 0.037 & 5.900 & 5.500 & 0.054 & 4.694 & 4.134 \\
\hline 1.00 & 0.038 & 4.910 & 4.310 & 0.057 & 3.754 & 3.120 \\
\hline 1.10 & 0.038 & 4.691 & 4.056 & 0.057 & 3.801 & 2.982 \\
\hline 1.20 & 0.039 & 5.117 & 4.404 & 0.059 & 4.041 & 3.159 \\
\hline 1.40 & 0.038 & 5.870 & 5.294 & 0.057 & 4.628 & 3.730 \\
\hline 1.60 & 0.037 & 6.562 & 5.978 & 0.056 & 5.245 & 4.188 \\
\hline 1.80 & 0.038 & 7.273 & 6.789 & 0.057 & 5.587 & 4.741 \\
\hline 2.00 & 0.041 & 8.003 & 7.606 & 0.062 & 5.915 & 5.390 \\
\hline
\end{tabular}

Table A3 $B_{d}$ values (port and starboard sides) for uni-directional waves $(\mathrm{s}=\infty)$ with $\gamma=3.3$ and $H_{S} \approx 0.04,0.06 m$

\begin{tabular}{|c|c|c|c|c|c|c|}
\hline$\gamma=1, H_{s} \approx 0.04 m$ & \multicolumn{3}{|c|}{$s=20$} & \multicolumn{3}{c|}{$s=5$} \\
\hline $\begin{array}{c}T_{p} \\
(s)\end{array}$ & $\begin{array}{c}H_{s} \\
(m)\end{array}$ & $\begin{array}{c}B_{d, \text { starboard }}(\mathrm{Nms}) \\
B_{d, \text { port }} \\
(\mathrm{Nms})\end{array}$ & $\begin{array}{c}H_{s} \\
(\mathrm{~m})\end{array}$ & $\begin{array}{c}B_{d, \text { starboard }} \\
(\mathrm{Nms})\end{array}$ & $\begin{array}{c}B_{d, \text { port }} \\
(\mathrm{Nms})\end{array}$ \\
\hline 0.70 & 0.028 & 6.796 & 5.133 & 0.027 & 6.678 & 5.194 \\
\hline 0.80 & 0.032 & 6.171 & 5.007 & 0.032 & 5.930 & 4.964 \\
\hline 0.90 & 0.035 & 5.144 & 4.295 & 0.035 & 5.026 & 4.044 \\
\hline 1.00 & 0.037 & 4.516 & 3.708 & 0.038 & 4.447 & 3.302 \\
\hline 1.10 & 0.039 & 4.221 & 3.327 & 0.039 & 4.070 & 2.981 \\
\hline 1.20 & 0.041 & 4.034 & 2.959 & 0.041 & 3.921 & 2.959 \\
\hline 1.40 & 0.041 & 3.994 & 2.828 & 0.041 & 3.996 & 3.040 \\
\hline 1.60 & 0.041 & 4.261 & 3.191 & 0.042 & 4.224 & 3.303 \\
\hline 1.80 & 0.042 & 4.654 & 3.506 & 0.042 & 4.614 & 3.517 \\
\hline 2.00 & 0.042 & 5.182 & 4.364 & 0.042 & 5.126 & 3.961 \\
\hline
\end{tabular}

Table A4 $B_{d}$ values (port and starboard sides) for multi-directional waves $(\mathrm{s}=20,5)$ with $\gamma=1$ and $H_{S} \approx 0.04 \mathrm{~m}$ 